\title{
Identification of Wheat Leaf Rust Resistance Genes in Chinese Wheat Cultivars and the Improved Germplasms
}

\author{
Hui Wu, Zhanhai Kang, Xing Li, ${ }^{\dagger}$ Yanyan Li, Yi Li, Shuo Wang, and Daqun Liu ${ }^{\dagger}$ \\ College of Plant Protection, Hebei Agricultural University/Technological Innovation Center for Biological Control of Crop Dis- \\ eases and Insect Pests of Hebei Province, Baoding, Hebei 071001, China
}

\begin{abstract}
Leaf rust is an important wheat disease that is a significant hindrance for wheat production in most areas of the world. Breeding resistant cultivars can effectively and economically control the disease. In the present study, a wheat collection consisting of 100 cultivars from China and 18 improved germplasms from global landrace donors together with 36 known single $\mathrm{Lr}$ gene lines were tested with 20 strains of Puccinia triticina Eriks. in the seedling stage to postulate the $L r$ gene in the cultivars and germplasms. In addition, 12 diagnostic molecular markers specific to $10 \mathrm{Lr}$ genes were used to detect the presence of the $L r$ genes in the wheat collection. Resistance to leaf rust of these cultivars at the adult plant stage

$L r 26, L r 33, L r 34, L r 45$, and $L r 46$ ) were identified in 44 wheat accessions, including 37 cultivars and seven improved germplasms. Among the 44 wheat accessions postulated with $L r$ genes, $L r l$ was present in four accessions, $L r 26$ in 12 accessions, $L r 33$ in two accessions, $L r 34$ in 14 accessions, Lr45 in three accessions, and Lr46 in 16 accessions. In the collection of 118 cultivars/germplasms, 34 wheat lines displayed adult-plant resistance carrying $\mathrm{Lr} 34, \mathrm{Lr} 46$, and/or underdetermined genes. Therefore, a high level of leaf rust resistance can be achieved through the combination of all-stage resistance and adult-plant resistance genes together in wheat cultivars.
\end{abstract} was tested in fields under natural infection during the 2016 to 2018 cropping seasons in Baoding, Hebei Province. The gene postulation combined with molecular marker detection showed that six $L r$ genes $(\operatorname{Lrl}$,

Keywords: wheat leaf rust, gene postulation, slow-rusting resistance, molecular marker

Leaf rust of wheat, caused by Puccinia triticina Eriks., is one of the most important diseases in wheat worldwide. The leaf rust pathogen can infect wheat plants in most growth stages in the cropping season. It mainly reduces the photosynthetic efficiency of wheat, resulting in the reduction of plant organic matter synthesis. Leaf rust can decrease grain quantity and quality and reduce wheat production by $40 \%$ in susceptible cultivars (Khan et al. 2013; Li et al. 2010). A severe leaf rust epidemic was reported in northwestern Mexico during 1976-1977 and caused 70\% yield losses (Dubin and Torres 1981). In China, leaf rust has been reported in the most winter-sown wheat production areas; for example, the most significant yield losses were documented in the provinces of Gansu, Sichuan, Shanxi, Henan, and Anhui in 2012 (Li et al. 2014; Zhou et al. 2013). Because wheat can be planted in different geographic and climatic conditions, the rust pathogens also have wider adaptation to survive in different environmental conditions. If the climate conditions are suitable for the rust pathogen and single resistant wheat varieties are planted in a large acreage, the resistance can be overcome by the emergence of the matching virulence in the rust population, leading to a disease pandemic. The use of rust resistant cultivars is the most economical

${ }^{\dagger}$ Corresponding authors: X. Li; lixing@ @ebau.edu.cn; D. Q. Liu; ldq@hebau.edu.cn

Hui Wu and Zhanhai Kang contributed equally to this work.

Funding: The Key Laboratory of Agricultural Integrated Pest Management, Academy of Agriculture and Forestry Sciences, Qinghai University Open Project (QHIIP-2020-01), Natural Science Foundation of Hebei Province (C2017204024), Colleges and Universities in Hebei Province Science and Technology Research Fund (ZD2017038).

* The $\boldsymbol{e}$-Xtra logo stands for "electronic extra" and indicates that there are supplementary materials published online.

The author(s) declare no conflict of interest.

Accepted for publication 1 April 2020.

(C) 2020 The American Phytopathological Society and efficient method to reduce the damage of the disease in a wide range of crops (Adhikari and Missaoui 2019; Hartman et al. 2005; Roelfs et al. 1992; Yu et al. 2018).

To date, more than 100 wheat leaf rust resistance $(L r)$ genes have been discovered, and 78 of them have been officially named (McIntosh et al. 2017). Most of them are effective through all wheat growth stages against leaf rust and can be easily identified in the seedling stage, known as all-stage resistance (ASR). This type of resistance is usually controlled by a single gene that starts expressing at the seedling stage (seedling resistance). However, some $L r$ genes often express at the adult plant stage. This type of resistance is known as adult-plant resistance (APR), further sorted as two types, racespecific and non-race-specific APR. Race-specific APR is characterized by a hypersensitive reaction around the rust pathogen infection sites such as $L r 12, L r 13, L r 22 a$ (Hiebert et al. 2007), Lr22b, Lr35, Lr37 (Seah et al. 2001), Lr48, and Lr49 (Bansal et al. 2008). Nonrace-specific APR is controlled by non-hypersensitive genes such as Lr34 (Dyck 1991), Lr46 (Singh et al. 1998), Lr67 (HerreraFoessel et al. 2011), and $\operatorname{Lr} 68$ (Herrera-Foessel et al. 2012). Wheat cultivars with a non-race-specific APR gene are characterized by slow disease progress with longer latent periods, low infection frequencies, smaller pustule size, and less spore production (Zhang et al. 2017). Although a single non-race-specific slow-rusting APR gene is susceptible or displays an intermediate reaction to leaf rust singly, a combination of four to five such genes can provide adequate resistance against the disease (Singh et al. 2000).

Rust resistance in wheat can be studied through genetic analysis, gene postulation, pedigree analysis, or marker-trait association analysis. Conventional genetic analysis includes making crosses, developing a segregated population, and evaluation of resistance in the population. It can provide essential information about the resistance in wheat, such as gene number, inheritance model, and the interaction of genes. Most of the officially named $L r$ genes were determined by this approach. This procedure is time-consuming and laborious. Morphological traits associated with resistance can be used as preliminary indicators to estimate the presence of the resistance gene. For example, wheat cultivars containing $L r 34, L r 46, L r 67$, and $\operatorname{Lr} 68$ have leaf tip necrosis (Herrera-Foessel et al. 2011, 2012; Singh 1992; Singh et al. 1998), and cultivars carrying Lr24 have red grains (McIntosh 1976). 
Table 1. The pedigree and origin of 118 wheat accessions

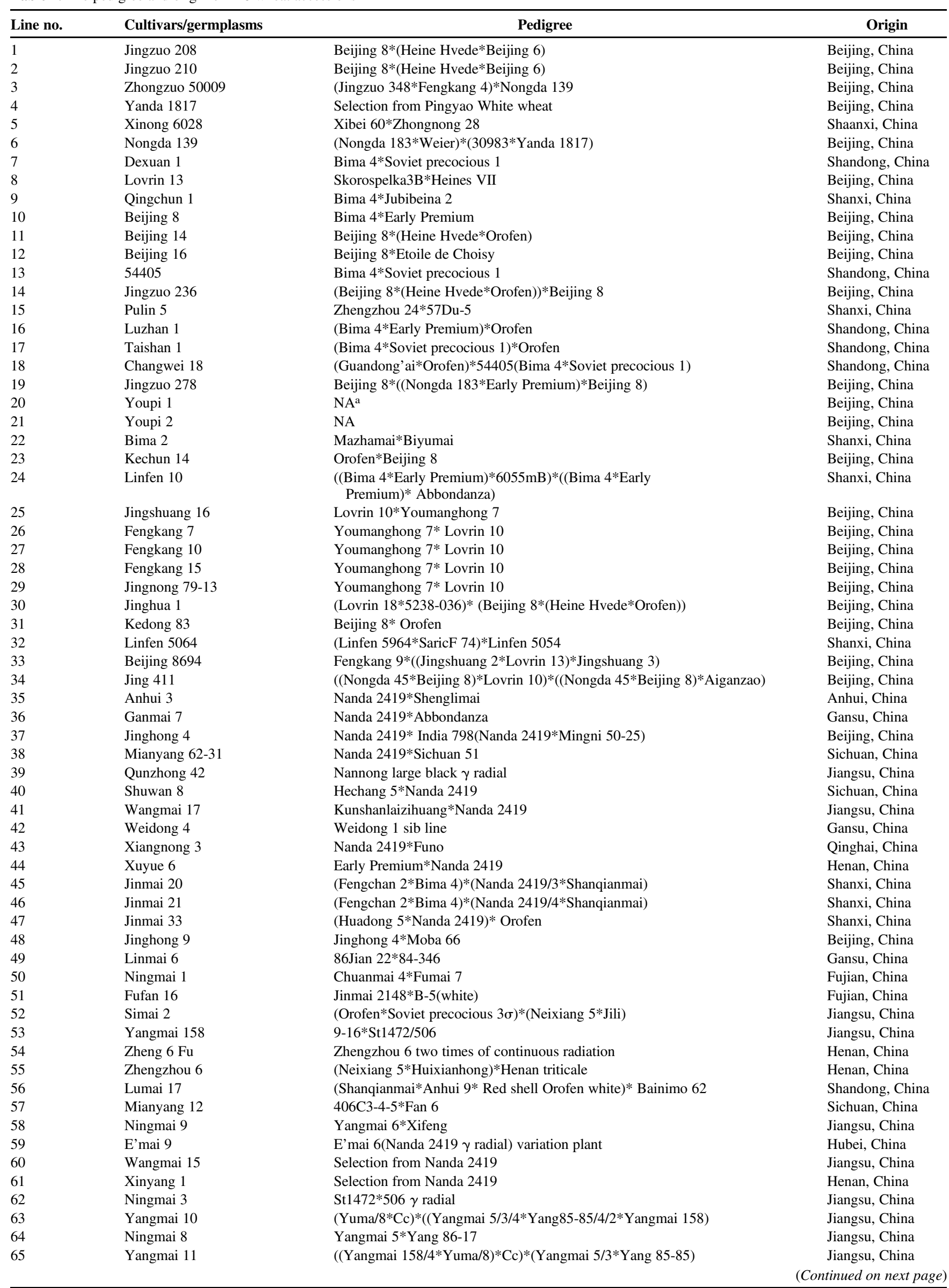

${ }^{\mathrm{a}} \mathrm{NA}=$ Not available. 
Table 1. (Continued from previous page)

\begin{tabular}{|c|c|c|c|}
\hline Line no. & Cultivars/germplasms & Pedigree & Origin \\
\hline$\overline{66}$ & Yangmai 13 & Yang $88-84 *($ Yangmai $3 *$ Marist Dove) & Jiangsu, China \\
\hline 67 & Yangmai 17 & Yang 92F101*Chunyu 21526 & Jiangsu, China \\
\hline 68 & Yang 85-85 & $\mathrm{Fu} 428 * 9-6-1-2$ & Jiangsu, China \\
\hline 69 & Jimai 26 & (Aiganhan*Lovrin 10 )*Jinfeng 1 & Hebei, China \\
\hline 70 & Zhengyin 4 & Mara*San Pastore & Henan, China \\
\hline 71 & Xiaoyan 4 & Fengchan $1 *$ Xiaoyan 96 & Shaanxi, China \\
\hline 72 & Xiaoyan 5 & St2422/464*Xiaoyan 96 & Shaanxi, China \\
\hline 73 & Zhengmai 9023 & (Xiaoyan 6*Xinong 65)*(83(2)3-3*84(14)43/3*Shan 213 & Henan, China \\
\hline 74 & Gaoyou 503 & $78506-2-4-6 * 845504$ & Beijing, China \\
\hline 75 & Huabei 187 & Shenglimai*Yanda 1817 & Beijing, China \\
\hline 76 & Nongda 311 & Shenglimai* Yanda 1817 & Beijing, China \\
\hline 77 & Beijing 5 & Selection from Huabei 187 & Beijing, China \\
\hline 78 & Beijing 6 & Selection from Huabei 187 & Beijing, China \\
\hline 79 & Beijng 10 & (Huabei $672 *$ Xinshi 14$) *($ Soviet precocious $1 *$ Huabei 672 ) & Beijing, China \\
\hline 80 & Hanxuan 10 & Nongda $16^{*}$ Huabei 187 & Shanxi, China \\
\hline 81 & Taiyuan 566 & Shenglimai*Yanda 1817 & Shanxi, China \\
\hline 82 & Taiyuan 116 & (Shenglimai*Yanda 1817)*Mingxian 169 & Shanxi, China \\
\hline 83 & Taiyuan 567 & Nongda $498^{*}$ Early Premium & Shanxi, China \\
\hline 84 & Hanxuan 1 & Nongda $16^{*}$ Huabei 187 & Shanxi, China \\
\hline 85 & Nanda 8 & Funo*Jiangdongmen & Jiangsu, China \\
\hline 86 & Zhengzhou 741 & St2422/464*Zhengzhou 17 & Henan, China \\
\hline 87 & Bimai 6 & Funo* Orofen & Guizhou, China \\
\hline 88 & Linnong 11 & Funo*Xinjiang Big seed & Gansu, China \\
\hline 89 & Linnong 12 & Funo*Xinjiang Big seed & Gansu, China \\
\hline 90 & Linnong 13 & NA & Gansu, China \\
\hline 91 & Yunmai 27 & Funo*rust resistance 1 (Orofen*Fuzhou white wheat) & Yunnan, China \\
\hline 92 & Suzhou 7829 & Funo*66-4768 & Jiangsu, China \\
\hline 93 & Pingliang 32 & NA & Gansu, China \\
\hline 94 & Shaan $6815-0-2-3$ & (Fengchan $3 *$ Funo)*Xibulai 81 & Shaanxi, China \\
\hline 95 & Jingzhou HXB7561-16 & Lovrin $13 *$ (Funo*Taiwan wheat) & Hubei, China \\
\hline 96 & Baiquan 565 & (Huixianhong*Funo)*Orofen & Henan, China \\
\hline 97 & Jingchun $70-5321$ & Funo*Orofen*Yindu 798 & Beijing, China \\
\hline 98 & Shaan 62(9)2-1 & (Danmai $1 *$ Funo)*58(18)2 & Shaanxi, China \\
\hline 99 & Xiannong 151 & (Fengchan $3 *$ Funo)*Jingmai 5 & Shaanxi, China \\
\hline 100 & Kezhen & (Songhuajiang $3 *$ Kehua)*(Funo*3/AD20) & Heilongjiang, China \\
\hline 101 & PI 660067 & AvS*PI 480294 & Ethiopia \\
\hline 102 & PI 660068 & AvS*PI 153779 & Egypt \\
\hline 103 & PI 660069 & AvS*PI 159918 & India \\
\hline 104 & PI 660071 & AvS*PI 178760 & Iraq \\
\hline 105 & PI 660072 & AvS*PI 180957 & India \\
\hline 106 & PI 660073 & AvS*PI 181410 & Afghanistan \\
\hline 107 & PI 660078 & AvS*PI 182121 & Pakistan \\
\hline 108 & PI 660087 & AvS*PI 189744 & Pakistan \\
\hline 109 & PI 660088 & AvS*PI 189749 & India \\
\hline 110 & PI 660092 & AvS*PI 192108 & Mozambique \\
\hline 111 & PI 660099 & AvS*PI 205726 & Peru \\
\hline 112 & PI 660106 & AvS*PI 268075 & Hungary \\
\hline 113 & PI 660110 & AvS*PI 436382 & Chile \\
\hline 114 & PI 660111 & AvS*PI 436384 & Chile \\
\hline 115 & PI 660113 & AvS*PI 479242 & Gansu, China \\
\hline 116 & PI 660115 & AvS*PI 479841 & Ethiopia \\
\hline 117 & PI 660123 & AvS*PI 620708 & U.S.A. \\
\hline 118 & PI 480016 & Landrace & U.S.A. \\
\hline
\end{tabular}

However, these morphological phenotypes are not stable, and their expressions are usually affected by environment conditions. DNA-based molecular markers are more stable and repeatable. Resistance gene linked markers have been extensively used in detecting resistance genes in wheat germplasms and in marker-assisted selection (MAS) for tracking resistance genes while breeding new wheat cultivars. Gene postulation is based on the gene-for-gene theory, which means a resistance phenotype is defined by the specific interaction between the resistance gene in the host and the corresponding determinator (avirulence) gene in the pathogen (Flor 1956). The responses of test lines are compared with the responses of an array of lines with known resistance genes when inoculated with sets of $P$. triticina pathotypes whose avirulence/virulence phenotypes are known (Dubin et al.
1989; Loegering et al. 1971). Although gene postulation has some drawbacks, such as difficulty for postulation of the slow-rusting gene and multiple genes or gene interaction in the cultivars, this approach can quickly estimate probable ASR genes in cultivars by appropriate experimental design. Kolmer (2003) used gene postulation to analyze soft red winter wheat in the U.S.A. and identified seven $L r$ genes in the test cultivars. When eliminating its drawbacks by combining it with pedigree analysis and molecular markers, gene postulation has been extensively used to understand leaf rust resistance in many wheat cultivars (Gao et al. 2019; Gebrewahid et al. 2017; Li et al. 2010; Randhawa et al. 2016; Yuan et al. 2007; Zhang et al. 2019).

China has a long history for wheat cultivation. Wheat landraces adapted to the local climatic conditions had been used by farmers for 
centuries until the modern wheat breeding programs were established around the 1930s (He et al. 2001; Zhou et al. 2007). The approaches of wheat improvement in China include introduction and reselection of cultivars/germplasms from other countries, hybridization between local landraces and exotic elite cultivars/germplasms, and creation of new germplasms by introgression of alien species (He et al. 2001). The leaf rust resistance in many modern Chinese cultivars was derived from local landraces, alien species, or introduction of international germplasms, such as Mentana, Ardito, Orofen, and Lovrin 10 (He et al. 2001). However, the leaf rust resistance can be easily overcome by new virulent rust pathotypes. Only a few $L r$ genes, $L r 9, L r 19, L r 24, L r 28, L r 29, L r 47$, $L r 51$, and $L r 53$, have resistance against prevalent $P$. triticina population in China (Li et al. 2010; Yuan et al. 2007).

The objective in this study was to identify the resistance in wheat cultivars and improved germplasms through gene postulation, molecular marker diagnostics, and pedigree analysis. Understanding the resistance in these wheat cultivars and identifying new resistance from germplasms will be valuable in wheat breeding for diversifying rust resistance in China.

\section{Materials and Methods}

Plant materials. One hundred wheat cultivars from 16 provinces in China and 18 improved germplasms from the National Small
Grain Collection (NSGC) of the U.S. Department of Agriculture (USDA) were to be postulated $L r$ genes (Table 1 ). A set of 36 wheat leaf rust differential lines differing for single $L r$ genes was used as reference (Table 2). A Chinese cultivar, Zhengzhou 5389, susceptible at both seedling and adult-plant stage to all $P$. triticina pathotypes in China, was used as control. Cultivar Saar, containing Lr34 and Lr46, was used as control for field adult-plant resistance test and Lr34 and Lr46 molecular marker test. The differential lines were kindly provided by USDA-ARS Cereal Disease Laboratory, University of Minnesota, St Paul, U.S.A., and seeds of 118 cultivars/ germplasms and Zhengzhou 5389 were provided by the Wheat Rust Laboratory of Hebei Agricultural University, China.

$P$. triticina races. Twenty $P$. triticina strains were used for characterization of the virulence/avirulence patterns in the wheat tester and the reference lines. These strains were collected from the main wheat production areas in China. The strains had various virulence/ avirulence combinations. They were identified to $12 P$. triticina races, which were the historically predominant reported races in China. Races FHJQ had six strains, and FGJQ, FHSQ, and FHJS each had two strains. Spores of all P. triticina strains were provided by the Wheat Rust Laboratory of Hebei Agricultural University, China. These races were named following the $P$. triticina nomenclature code system described by Long and Kolmer (1989), with the

Table 2. Infection types ${ }^{\mathrm{a}}$ of 36 Lr-gene differential lines inoculated with 20 Puccinia triticina strains

\begin{tabular}{|c|c|c|c|c|c|c|c|c|}
\hline \multirow[b]{2}{*}{ Line no. } & \multirow[b]{2}{*}{$L r$ genes } & \multicolumn{7}{|c|}{ Infection types a to $P$. triticina pathotypes } \\
\hline & & KHJS & THTS & PHSQ & FCJS & PHJS & PHTS & $\overline{\text { PHJQ }}$ \\
\hline$\overline{1}$ & RL6003 (Lrl) & 1 & 4 & 3 & $; 1$ & $3+$ & 4 & 4 \\
\hline 2 & RL6016 (Lr2a) & 3 & 4 & 2 & 1 & 1 & 2 & 2 \\
\hline 3 & RL6047 (Lr2c) & 4 & 4 & 4 & $3+$ & $3+$ & $3+$ & 4 \\
\hline 4 & RL6002 (Lr3) & 4 & 4 & 4 & 4 & $3+$ & 4 & 4 \\
\hline 5 & RL6010 ( Lr9) & 0 & 0 & 0 & 0 & 0 & 0 & 0 \\
\hline 6 & RL6005 (Lr16) & 3 & $3+$ & $3+$ & 4 & $3+$ & 4 & 4 \\
\hline 7 & RL6064 (Lr24) & ; & ; & $; 1$ & ; & ; & ; & ; \\
\hline 8 & RL6078 (Lr26) & 4 & $3-$ & $3+$ & $3+$ & $3+$ & $3+$ & 3 \\
\hline 9 & RL6007 (Lr3ka) & 2 & 4 & 3 & 2 & 2 & 4 & 2 \\
\hline 10 & RL605 (Lr11) & $3+$ & 3 & $3+$ & 3 & 3 & 4 & $3+$ \\
\hline 11 & RL6008 (Lr17) & 4 & $3+$ & 4 & $3+$ & $3+$ & 4 & 3 \\
\hline 12 & RL6049 (Lr30) & 1 & 4 & 1 & 1 & 1 & 4 & 1 \\
\hline 13 & RL6051 $(\operatorname{LrB})$ & 4 & $3+$ & $3+$ & $3+$ & $3+$ & 4 & 3 \\
\hline 14 & RL6004 ( $\operatorname{Lr} 10)$ & $3+$ & $3+$ & $3+$ & $3+$ & $3+$ & 4 & $3+$ \\
\hline 15 & RL6013 (Lr14a) & 3 & 4 & $\mathrm{X}$ & 3 & $3+$ & 4 & $2+$ \\
\hline 16 & RL6009 (Lr18) & 1 & 1 & 1 & 1 & 1 & 2 & 2 \\
\hline 17 & RL6019 (Lr2b) & $3+$ & 4 & 3 & 1 & 1 & $2+$ & 2 \\
\hline 18 & RL6042 (Lr3bg) & $3+$ & 4 & $3+$ & $3+$ & $3+$ & $3+$ & 3 \\
\hline 19 & RL4031 (Lr13) & $3+$ & 4 & $3+$ & 23 & $3+$ & $3+$ & $3+$ \\
\hline 20 & RL6006 (Lr14b) & 4 & 4 & $3+$ & 3 & $3+$ & 4 & 4 \\
\hline 21 & RL6052 (Lr15) & 0 & 4 & 4 & 3 & 4 & 1 & 1 \\
\hline 22 & RL6040 (Lr19) & 0 & 0 & 0 & 0 & 0 & 0 & 0 \\
\hline 23 & RL6092 (Lr20) & ; & ; & 1 & 1 & $3+$ & 1 & 1 \\
\hline 24 & RL6043 (Lr21) & 2 & 3 & 2 & 2 & 2 & 3 & $2+$ \\
\hline 25 & RL6012 (Lr23) & 3 & $3+$ & 3 & 3 & $3+$ & $3+$ & 3 \\
\hline 26 & $\mathrm{R} 16079(\operatorname{Lr} 28)$ & 0 & 0 & 0 & ; & 0 & 0 & 0 \\
\hline 27 & R16080 (Lr29) & ; & $;, 1$ & $; 1$ & $;, 1$ & 1 & $; 1$ & 1 \\
\hline 28 & RL6057 (Lr33) & $3+$ & 3 & 3 & $3,2+$ & 2 & 3 & 3 \\
\hline 29 & $\mathrm{E} 84018(\operatorname{Lr} 36)$ & 2 & 1 & 3 & 3 & $2+$ & 3 & $3 c$ \\
\hline 30 & KS91 (Lr39) & $3+$ & 3 & $3+$ & 3 & $3+$ & $3+$ & $3+$ \\
\hline 31 & WGRC11 (Lr42) & 3 & 2 & 3 & 3 & 3 & 2,3 & $3 \mathrm{c}$ \\
\hline 32 & RL6147 (Lr44) & $3+$ & 3 & 3 & 3 & 1 & $3+$ & 3 \\
\hline 33 & RL6144 (Lr45) & 4 & $3+$ & 3 & 1 & $3+$ & $3+$ & $2,3+$ \\
\hline 34 & C98.006 ( Lr47) & 0 & 0 & 0 & 0 & 0 & 0 & 0 \\
\hline 35 & $\mathrm{C} 78.5(\operatorname{Lr} 51)$ & 0 & ; & 0 & $; 1$ & ; & 0 & ; \\
\hline 36 & 98M71 (Lr53) & 0 & 0 & 0 & 0 & 0 & 0 & 0 \\
\hline 37 & Zhengzhou 5389 & 4 & 4 & 4 & $3+$ & $3+$ & 4 & 4 \\
\hline
\end{tabular}

\footnotetext{
a According to the 0 to 4 Stakman scale. $0=$ no flecks or uredinia, ; = hypersensitive flecks, $1=$ small uredinia with necrosis, $2=$ small uredinia with chlorosis, $3=$ moderate size uredinia, 4 = large uredinia, + indicates slightly larger uredinia, - indicates slightly smaller uredinia, $\mathrm{C}$ indicates more chlorosis than normal for the infection type, $\mathrm{X}$ indicates random distribution of variable-sized uredinia.
} 
addition of a fourth letter for the reactions to the fourth quartet of differentials (https://www.ars.usda.gov/ARSUserFiles/50620500/Cerealrusts/pt_nomen.pdf).

Seedling testing. The pathogenicity of all wheat accessions was tested in a controlled greenhouse condition in November to December in 2017. Five seeds of each known $L r$-gene differential line, cultivar, improved germplasm, and Zhengzhou 5389 were sowed in plastic pots $(3 \times 2 \mathrm{~cm})$ filled with soil mixture and placed in a growth chamber at 18 to $22^{\circ} \mathrm{C}$ with a diurnal cycle of $16 \mathrm{~h} \mathrm{light} / 8 \mathrm{~h}$ dark. The test plants were inoculated by each of $20 P$. triticina strains when the first leaf completely unfolded. Test plants were brushed against fully sporulating Zhengzhou 5389 plants (Wang et al. 2014). Inoculated plants were incubated in a dew chamber in the dark at $18^{\circ} \mathrm{C}$ and $100 \%$ relative humidity $(\mathrm{RH})$ for $24 \mathrm{~h}$. Then, the plants were transferred to a growth chamber at 18 to $22^{\circ} \mathrm{C}$ and $75 \% \mathrm{RH}$ with a diurnal cycle of $16 \mathrm{~h}$ light $/ 8 \mathrm{~h}$ dark. The infection types (ITs) were recorded 14 days after inoculation with a 0 to 4 scale (Roelfs et al. 1992). Plants with IT 0 to $2+$ were considered as low IT (resistance), and 3 to 4 considered as high IT (susceptible). The gene postulation was conducted using the method proposed by Dubin et al. (1989).

Field testing. All 118 wheat accessions, susceptible check Zhengzhou 5389, and slow-rusting check Saar were evaluated for leaf rust reaction in the field nurseries at Baoding in Hebei Province $\left(115.47^{\circ} \mathrm{E}, 38.85^{\circ} \mathrm{N}\right)$ during the 2016 to 2018 cropping seasons Field tests were designed with randomized complete blocks with three replicates at each location. Fifty seeds of each cultivar were sown in single rows ( $1.5 \mathrm{~m}$ length and $25 \mathrm{~cm}$ between rows). The susceptible cultivar Zhengzhou 5389 was planted one row following every 10 test accessions, and adjacent and perpendicular to the test blocks in order to spread spores within the trials. Epidemics were initiated by spraying aqueous spore suspensions, containing equal amounts of mixed spores of four $P$. triticina races THTT, THTS, THTQ, and PHPS in Tween $20(0.03 \%)$ solution, onto the spreader plants of Zhengzhou 5389 at the tillering stage in the spring. The final disease severity (FDS) was recorded according to the method proposed by Li et al. (2010).

Statistical analysis. Analysis of variance (ANOVA) was performed using the generalized linear model procedure (PROC MIX) of Statistical Analysis System (Version 9.1. SAS Institute Inc. Cary, NC, U.S.A.). Cultivars, environments (the combination of location and year), and their interaction were treated as fixed effects, and replications nested in environments were as random. Fisher's least significant difference (LSD) test at $P=0.05$ was used to separate the treatment means of FDS (Sokal and Rohlf 1989). Genotypes with high ITs to mixed $P$. triticina races at the seedling stage and low FDS values (less than 60\%) in the field were considered to have slow-rusting resistance.

Table 2. (Continued from previous page)

\begin{tabular}{|c|c|c|c|c|c|c|c|c|c|c|c|c|}
\hline \multicolumn{13}{|c|}{ Infection types a to $P$. triticina pathotypes } \\
\hline THND & FHJQ-1 & FHJQ-2 & FHJQ-3 & FHJQ-4 & FHJQ-5 & FHJQ-6 & FGJQ-1 & FGJQ-2 & FHSQ-1 & FHSQ-2 & FHJS-1 & FHJS-2 \\
\hline 4 & 1 & 1 & 1 & 1 & $; 1$ & 2 & 1 & 1 & 1 & 1 & 3 & ; \\
\hline 4 & 1 & 2 & 2 & 2 & $1+$ & 2 & 2 & $1+$ & $2+$ & $2+$ & 2 & $2+$ \\
\hline 4 & 4 & 4 & 4 & $3+$ & 4 & 4 & $3+$ & 4 & 3 & 3 & 4 & $3+$ \\
\hline 4 & 4 & $3+$ & 4 & $3+$ & 4 & 4 & 4 & 4 & $3+$ & $3+$ & 4 & $3+$ \\
\hline 0 & ; & 0 & 0 & 0 & 0 & 0 & 0 & 0 & 0 & 0 & 0 & ; \\
\hline $3+$ & $3+$ & $3+$ & $3+$ & $3+$ & $3+$ & $3+$ & $3+$ & $3+$ & $3+$ & 3 & 4 & $3+$ \\
\hline ; & $;, 1$ & ; & ; & ; & ; & ; & ; & ; & ; & ; & 1 & ; \\
\hline $3+$ & $3+$ & 3 & $3+$ & $3+$ & $3+$ & $3+$ & 1 & 1 & $2+, 3 c$ & $3+$ & 4 & 3 \\
\hline $3+$ & 2 & 2 & 2 & 2 & 2 & 2 & 2 & 2 & 3 & 3 & 2 & $2+$ \\
\hline 1 & $3+$ & $3+$ & $3+$ & 3 & 3 & 3 & $3+$ & $3+$ & 3 & $3,3 \mathrm{c}$ & $3+$ & $3+$ \\
\hline $3+$ & $3+$ & $3+$ & $3+$ & 3 & $3+$ & $3+$ & $3+$ & 3 & 3 & 3 & 3 & $3+$ \\
\hline 1 & 2 & $1+$ & $; 1$ & 2 & 1 & 1 & 2 & 1 & 2 & 1 & 2 & 2 \\
\hline $3+$ & $3+$ & $3+$ & $3+$ & $3+$ & $3+$ & $3+$ & $3+$ & $3+$ & 3 & $3+$ & $3+$ & $3+$ \\
\hline $2+$ & $3+$ & $3+$ & $3+$ & $3+$ & $3+$ & $3+$ & $3+$ & $3+$ & 3 & $3+$ & $3+$ & 3 \\
\hline 4 & $X$ & 2 & 2 & $X$ & $X$ & $X$ & $X$ & $X$ & 2 & $X$ & 3 & $3 c$ \\
\hline 1 & 1 & 1 & 1 & 1 & 1 & 1 & 1 & 1 & 1 & 1 & 1 & 1 \\
\hline 4 & 3 & $3+$ & 3 & 3 & 3 & 3 & 2 & 2 & 3 & $3+$ & 3 & 3 \\
\hline 4 & $3+$ & $3+$ & 3 & $3+$ & $3+$ & 4 & 3 & $3+$ & 3 & $3+$ & $3+$ & 3 \\
\hline 4 & 3 & 3 & 3 & 3 & $3+$ & $3+$ & $2+$ & $2+$ & $3+$ & $3+$ & $2+$ & $2+$ \\
\hline 4 & $3+$ & $3+$ & 4 & 3 & $3+$ & 4 & $3+$ & $3+$ & 3 & $3+$ & 4 & 3 \\
\hline 4 & 1 & 0 & 3 & 0 & 0 & 1 & 4 & 1 & $3+$ & ; & 1 & 1 \\
\hline 0 & 0 & 0 & 0 & 0 & 0 & 0 & 0 & 0 & 0 & 0 & 0 & 0 \\
\hline 1 & ; & ; & 1 & ; & 1 & 1 & 1 & 1 & 1 & ; & 1 & 1 \\
\hline 3 & 2 & 2 & 1 & 1 & 1 & $2+$ & 1 & 2 & 2 & 2 & 2 & 3 \\
\hline 4 & $3+$ & $3+$ & $3+$ & 3 & $3+$ & $3+$ & 3 & 3 & $3+$ & 3 & $3+$ & 3 \\
\hline 0 & 0 & 0 & 0 & 0 & 0 & 0 & 0 & 0 & 0 & 0 & 0 & 0 \\
\hline ; & 1 & 1 & 1 & 1 & ; & $; 1$ & $1+$ & 1 & 1 & 1 & 1 & ; \\
\hline 3 & $3+$ & $3+$ & 3 & 3 & 3 & 3 & 3 & 3 & 3 & 3 & 3 & 3 \\
\hline 1 & 3 & 3 & 3 & 3 & 3 & 3 & 2 & 3 & $2+$ & $3 c$ & $3+$ & 3 \\
\hline 3 & 3 & $3+$ & 3 & 3 & $3,3 \mathrm{c}$ & 3 & $3+$ & 3 & 3 & 3 & 3 & 3 \\
\hline 2 & 3 & $3+$ & $3+$ & 3 & 3 & 3 & $3+$ & 3 & 3 & 3 & 3 & 3 \\
\hline 2 & 3 & $3+$ & $3+$ & 3 & 3 & 3 & 3 & 3 & 3 & 3 & 3 & 3 \\
\hline $3+$ & 4 & $3+$ & $3+$ & 4,2 & $3+$ & $2,3+$ & ;3+ & $3+$ & $1,3+$ & $3+$ & $3+$ & $3+$ \\
\hline 0 & 0 & 0 & 0 & 0 & 0 & 0 & 0 & 0 & 0 & 0 & 0 & 0 \\
\hline ; & ; & 1 & ; & 0 & ; & ; & ; & ; & ; & ; & ; & ; \\
\hline 0 & 0 & 0 & 0 & 0 & 0 & 0 & 0 & 0 & 0 & 0 & 0 & 0 \\
\hline 4 & 4 & 4 & 4 & $3+$ & $3+$ & 4 & $3+$ & 4 & 4 & 3 & 4 & $3+$ \\
\hline
\end{tabular}


Marker for leaf rust resistance gene. The plants were grown in a greenhouse and leaves of each plant were collected at the two-leaf stage. Genomic DNA was extracted from each wheat accession according to the modified CTAB method (Sharp et al. 1988) and the concentration and purity of DNA were measured by a spectrophotometer (NanoDrop ND-1000, Wilmington, DE, U.S.A.). Molecular markers linked to the 10 known $L r$ genes $(L r 1, L r 9, L r 10, \operatorname{Lr} 19, \operatorname{Lr} 20, \operatorname{Lr} 24, \operatorname{Lr} 26, \operatorname{Lr} 34, \operatorname{Lr} 37$, and $L r 46$ ) were used for detecting the presence of the genes in the test wheat accessions. The sequences, annealing temperatures, and $L r$ gene linked alleles of these markers are provided in Table 3. PCR was performed following the protocols of the original publications (Table 3). Genomic DNA from wheat lines carrying the known $L r$ genes was included as a reference in each marker test. The PCR products of STS markers were separated on $1.5 \%$ agarose gel and stained with ethidium bromide for $20 \mathrm{~min}$. The PCR products of SSR markers were separated on 12\% nondenaturing polyacrylamide gel and stained with silver nitrogen.

\section{Results}

$\boldsymbol{L r}$ gene postulation. Zhengzhou 5389 showed high ITs to each of 20 P. triticina strains (IT 4). Nine $L r$ genes ( $L r 9, L r 18, L r 19, L r 24$, Lr28, Lr29, Lr47, Lr51, and Lr53) showed low ITs to 20 P. triticina strains, and nine $L r$ genes ( $L r 2 c, L r 3, L r 16, L r 17, L r B, L r 3 b g, L r 14 b$, $L r 23$, and Lr39) had high ITs to all P. triticina strains. Thus, it is impossible to postulate the presence of these $18 \mathrm{Lr}$ genes based on the test $P$. triticina strains. The remaining 18 out of $36 \mathrm{Lr}$ genes could be postulated based on their IT patterns on the $20 P$. triticina strains.

According to the IT patterns of the 118 wheat accessions produced by $20 P$. triticina strains (Table 4) and diagnostic alleles of the molecular markers associated, four seedling resistance $L r$ genes, $L r 1, L r 26, L r 33$, and $L r 45$, were identified in 22 wheat accessions, including four improved germplasms and 18 cultivars. $\mathrm{Lrl}$ was present in four (3.4\%) wheat accessions, $L r 26$ in 12 (10.2\%) accessions, $L r 33$ in two $(1.7 \%)$ accessions, and $L r 45$ in three (2.5\%) accessions. The reaction patterns of 57 accessions were different from the response of any known $L r$ gene or any gene combination, so these accessions contain unidentified $L r$ gene(s). On the other hand, 51 accessions displayed high ITs to all tested $P$. triticina strains, indicating that the seedling $L r$ gene(s) could not be postulated.

Lrl showed low ITs to 13 P. triticina strains, KHJS, FCJS, FHJQ1, FHJQ-2, FHJQ-3, FHJQ-4, FHJQ-5, FHJQ-6, FGJQ-1, FGJQ-2, FHSQ-1, FHSQ-2, and FHJS-2, and high ITs to the other seven strains. Four wheat accessions (Luzhan 1, Taishan 1, Linfei 10, PI 660011) showed similar avirulence/virulence patterns as the $\mathrm{LrI}$ gene (Tables 2 and 4). The presence of the Lrl gene in these four wheat lines was confirmed by marker Lr1_WR003.

Lr26 showed low ITs to two strains, FGJQ-1 and FGJQ-2, and high ITs to the other 18 strains. Twelve cultivars were postulated carrying Lr26 gene. Four cultivars (Fengkang 7, Jinghua 1, Beijing 8694, Jinmai 33) had similar avirulence/virulence patterns as $\operatorname{Lr} 26$ and had the same alleles as the Lr26 gene in marker loci Lr26- $\omega$-secalin and Lr26_Glu-B3. Eight cultivars had additional resistance to the test $P$. triticina strains. Except to strains FGJQ-1 and FGJQ-2, Lovrin 13 was resistant to strains KHJS, THTS, and PHJQ, Taishan 1 resistant to KHJS, PHSQ, FCJS, PHJS, FHJQ-1,FHJQ-2, FHJQ-3, FHJQ-4, FHJQ-5, FHJQ-6, FHSQ-1, FHSQ-2, FHJS-1, and FHJS2, Fengkang 10 and Jimai 26 both resistant to THTS and FHJQ-5,

Table 3. PCR primers and their conditions for detecting leaf rust resistance $(L r)$ genes as well as specific fragment sizes

\begin{tabular}{|c|c|c|c|c|c|c|}
\hline \multirow{2}{*}{$\begin{array}{l}L r \\
\text { gene }\end{array}$} & \multicolumn{2}{|r|}{ Primer } & \multirow[b]{2}{*}{ Reaction condition } & \multirow{2}{*}{$\begin{array}{l}\text { Size } \\
\text { (bp) }\end{array}$} & \multirow{2}{*}{$\begin{array}{l}\text { Genetic distance } \\
(\mathrm{cM})\end{array}$} & \multirow[b]{2}{*}{ Reference } \\
\hline & Name & Sequence $\left(5^{\prime}-3^{\prime}\right)$ & & & & \\
\hline \multirow[t]{2}{*}{ Lrl } & WR003F & GGGACAGAGACCTTGGTGGA & \multirow{2}{*}{$\begin{array}{l}94^{\circ} \mathrm{C} 5 \mathrm{~min} ; 35 \text { cycles }\left(94^{\circ} \mathrm{C} 1\right. \\
\left.\min ; 62^{\circ} \mathrm{C} 1 \mathrm{~min} ; 72^{\circ} \mathrm{C} 1 \mathrm{~min}\right) \\
72^{\circ} \mathrm{C} 10 \mathrm{~min} ; 10^{\circ} \mathrm{C} \text { forever }\end{array}$} & \multirow[t]{2}{*}{760} & \multirow[t]{2}{*}{ Cosegregated } & \multirow[t]{2}{*}{ Qiu et al. (2007) } \\
\hline & WR003R & GACGATGATGATTTGCTGCTGG & & & & \\
\hline \multirow[t]{2}{*}{$\operatorname{Lr} 9$} & $\mathrm{~J} 13 / 1$ & TCCTTTTATTCCGCACGCCGG & \multirow{2}{*}{$\begin{array}{l}94^{\circ} \mathrm{C} 6 \mathrm{~min} ; 35 \text { cycles }\left(94^{\circ} \mathrm{C} 1\right. \\
\left.\min ; 68.5^{\circ} \mathrm{C} 1 \mathrm{~min} ; 72^{\circ} \mathrm{C} 2 \mathrm{~min}\right) \\
72^{\circ} \mathrm{C} 10 \mathrm{~min} ; 10^{\circ} \mathrm{C} \text { forever }\end{array}$} & \multirow[t]{2}{*}{1,100} & \multirow[t]{2}{*}{ Cosegregated } & \multirow{2}{*}{$\begin{array}{l}\text { Schachermayr et al. } \\
\text { (1994) }\end{array}$} \\
\hline & $\mathrm{J} 13 / 2$ & CCACACTACCCCAAAGAGACG & & & & \\
\hline \multirow[t]{2}{*}{$\operatorname{Lr} 10$} & Lrk10D1 & GAAGCCCTTCGTCTCATCTG & \multirow{2}{*}{$\begin{array}{l}94^{\circ} \mathrm{C} 3 \mathrm{~min} ; 35 \text { cycles }\left(94^{\circ} \mathrm{C} 45 \mathrm{~s}\right. \\
\left.60^{\circ} \mathrm{C} 45 \mathrm{~s} ; 72^{\circ} \mathrm{C} 30 \mathrm{~s}\right) ; 72^{\circ} \mathrm{C} 3 \\
\min ; 10^{\circ} \mathrm{C} \text { forever }\end{array}$} & \multirow[t]{2}{*}{282} & \multirow[t]{2}{*}{ Cosegregated } & \multirow{2}{*}{$\begin{array}{l}\text { Schachermayr et al. } \\
\text { (1997) }\end{array}$} \\
\hline & Lrk10D2 & TTGATTCATTGCAGATGAGATCACG & & & & \\
\hline \multirow[t]{2}{*}{$\operatorname{Lr} 19$} & SCS265-F & GGCGGATAAGCAGAGCAGAG & \multirow{2}{*}{$\begin{array}{l}94^{\circ} \mathrm{C} 5 \mathrm{~min} ; 35 \text { cycles }\left(94^{\circ} \mathrm{C} 1\right. \\
\left.\min ; 65^{\circ} \mathrm{C} 1 \mathrm{~min} ; 72^{\circ} \mathrm{C} 2 \mathrm{~min}\right) \\
72^{\circ} \mathrm{C} 10 \mathrm{~min} ; 10^{\circ} \mathrm{C} \text { forever }\end{array}$} & \multirow[t]{2}{*}{512} & \multirow[t]{2}{*}{ Cosegregated } & \multirow[t]{2}{*}{ Gupta et al. (2006) } \\
\hline & SCS265-R & GGCGGATAAGTGGGTTATGG & & & & \\
\hline \multirow[t]{2}{*}{$\operatorname{Lr} 19$} & SCS253-F & GCTGGTTCCACAAAGCAAA & \multirow{2}{*}{$\begin{array}{l}94^{\circ} \mathrm{C} 5 \mathrm{~min} ; 35 \text { cycles }\left(94^{\circ} \mathrm{C} 1\right. \\
\left.\min ; 60^{\circ} \mathrm{C} 1 \mathrm{~min} ; 72^{\circ} \mathrm{C} 2 \mathrm{~min}\right) \\
72^{\circ} \mathrm{C} 10 \mathrm{~min} ; 10^{\circ} \mathrm{C} \text { forever }\end{array}$} & \multirow[t]{2}{*}{736} & \multirow[t]{2}{*}{ Cosegregated } & \multirow[t]{2}{*}{ Gupta et al. (2006) } \\
\hline & SCS253-R & GGCTGGTTCCTTAGATAGGTG & & & & \\
\hline \multirow[t]{2}{*}{ Lr20 } & STS638-L & ACAGCGATGAAGCAATGAAA & \multirow{2}{*}{$\begin{array}{l}94^{\circ} \mathrm{C} 5 \mathrm{~min} ; 35 \text { cycles }\left(94^{\circ} \mathrm{C} 1\right. \\
\left.\min ; 63^{\circ} \mathrm{C} 1 \mathrm{~min} ; 72^{\circ} \mathrm{C} 2 \mathrm{~min}\right) \\
72^{\circ} \mathrm{C} 10 \mathrm{~min} ; 10^{\circ} \mathrm{C} \text { forever }\end{array}$} & 542 & Complete linkage & Neu et al. (2002) \\
\hline & STS638-R & GTCCAGTTGGTTGATGGAAT & & & & \\
\hline $\operatorname{Lr} 24$ & $\mathrm{~J} 09 / 1$ & TCTAGTCTGTACATGGGGGC & $94^{\circ} \mathrm{C} 5 \mathrm{~min} ; 35$ cycles $\left(94^{\circ} \mathrm{C} 1\right.$ & 310 & Complete linkage & Schachermayr et al. \\
\hline & $\mathrm{J} 09 / 2$ & TGGCACATGAACTCCATACG & $\begin{array}{l}\left.\min ; 60^{\circ} \mathrm{C} 1 \mathrm{~min} ; 72^{\circ} \mathrm{C} 2 \mathrm{~min}\right) \\
72^{\circ} \mathrm{C} 10 \mathrm{~min} ; 10^{\circ} \mathrm{C} \text { forever }\end{array}$ & & & (1995) \\
\hline $\operatorname{Lr} 26$ & $\omega$-secalinF & АССТTCCTCATCTTTGTCCT & $94^{\circ} \mathrm{C} 5 \mathrm{~min} ; 35$ cycles $\left(94^{\circ} \mathrm{C} 1\right.$ & 1,076 & Cosegregated & Chai et al. (2006) \\
\hline & $\omega$-secalinR & CCGATGCCTATACCACTACT & $\begin{array}{l}\left.\min ; 65^{\circ} \mathrm{C} 1 \mathrm{~min} ; 72^{\circ} \mathrm{C} 2 \mathrm{~min}\right) \\
72^{\circ} \mathrm{C} 10 \mathrm{~min} ; 10^{\circ} \mathrm{C} \text { forever }\end{array}$ & & & \\
\hline $\operatorname{Lr} 26$ & Glu-B3F & GGTACCAACAACAACAACCC & $94^{\circ} \mathrm{C} 5 \mathrm{~min} ; 35$ cycles $\left(94^{\circ} \mathrm{C} 1\right.$ & 636 & Cosegregated & de Froidmont (1998) \\
\hline & Glu-B3R & GTTGCTGCTGAGGTTGGTTC & $\begin{array}{l}\left.\min ; 65^{\circ} \mathrm{C} 1 \mathrm{~min} ; 72^{\circ} \mathrm{C} 2 \mathrm{~min}\right) \\
72^{\circ} \mathrm{C} 10 \mathrm{~min} ; 10^{\circ} \mathrm{C} \text { forever }\end{array}$ & & & \\
\hline Lr34 & csLv34F & GTTGGTTAAGACTGGTGATGG & $94^{\circ} \mathrm{C} 5 \mathrm{~min} ; 35$ cycles $\left(94^{\circ} \mathrm{C} 1\right.$ & 150 & 0.4 & Lagudah et al. (2006) \\
\hline & $\operatorname{csLv} 34 \mathrm{R}$ & TGCTTGCTATTGCTGAATAGT & $\begin{array}{l}\left.\min ; 57^{\circ} \mathrm{C} 1 \mathrm{~min} ; 72^{\circ} \mathrm{C} 2 \mathrm{~min}\right) \\
72^{\circ} \mathrm{C} 10 \mathrm{~min} ; 10^{\circ} \mathrm{C} \text { forever }\end{array}$ & & & \\
\hline Lr37 & VENTRIUP & AGGGGCTACTGACCAAGGCT & $94^{\circ} \mathrm{C} 5 \mathrm{~min} ; 32$ cycles $\left(94^{\circ} \mathrm{C} 50 \mathrm{~s}\right.$ & 259 & Cosegregated & Helguera et al. \\
\hline & LN2 & TGCAGCTACAGCAGTATGTACACAAAA & $\begin{array}{l}\left.65^{\circ} \mathrm{C} 50 \mathrm{~s} ; 72^{\circ} \mathrm{C} 1 \mathrm{~min}\right) ; 72^{\circ} \mathrm{C} 10 \\
\mathrm{~min} ; 10^{\circ} \mathrm{C} \text { forever }\end{array}$ & & & (2003) \\
\hline Lr46 & csLV46G22-F & TCGACTTTGGAATGGAGTTGC & $94^{\circ} \mathrm{C} 5 \mathrm{~min} ; 35$ cycles $\left(94^{\circ} \mathrm{C} 1\right.$ & 520 & Complete linkage & E. S. Lagudah, \\
\hline & csLV46G22-R & GGCGAAGATGCCATCATCCACCAG & $\begin{array}{l}\left.\min ; 60^{\circ} \mathrm{C} 1 \mathrm{~min} ; 72^{\circ} \mathrm{C} 2 \mathrm{~min}\right) \\
72^{\circ} \mathrm{C} 10 \mathrm{~min} ; 10^{\circ} \mathrm{C} \text { forever } \\
\text { Enzyme digestion: } 37^{\circ} \mathrm{C} 2 \mathrm{~h} \text {; } \\
80^{\circ} \mathrm{C} 30 \mathrm{~min} ; 10^{\circ} \mathrm{C} \text { forever }\end{array}$ & & & tonnblichod \\
\hline
\end{tabular}


Simai 2 resistant to FHSQ-1, FHSQ-2, and FHJS-1, Jingchun 705321 resistant to THTS and FHJQ-2, Jingnong 79-13 resistant to THTS, and Jingzhou HXB7561-16 resistant to FHJQ-3. The same alleles in two marker loci of $L r 26$ were detected in these eight cultivars. The resistance to leaf rust in these eight cultivars was conferred by $L r 26$ and additional unidentified $L r$ gene(s).

Lr33 showed low ITs (IT 2) to PHJS and high ITs in the other 19 strains (Table 2). Improved germplasms PI 660113 and PI 660067 were postulated carrying Lr33, for they had similar aivirulence/ virulence patterns on 20 P. triticina strains as Lr33 (Table 4).

Lr45 had low IT (IT 1) to FCJS and high ITs on the other 19 strains (Table 2). Three wheat accessions were postulated carrying Lr45. Nanda 8, Yunmai 27, and PI 660073 had similar avirulence/ virulence patterns against $20 \mathrm{P}$. triticina strains as the Lr45 differential line.

Postulated adult-plant resistance genes by field test and molecular markers. The analysis of variance for FDS (at $P \leq$ 0.05 ) of the tested wheat accessions showed the significant differences between genotype, environment, and genotype-environment interactions in the field trials (Table 5). This indicated that adultplant resistance was influenced by genotype, environment and genotype-environment interactions. There were no significant differences among years and replications.

In both cropping seasons, the mean FDS value of susceptible check Zhengzhou 5389 was 80 to $100 \%$ while it was 1 to $3 \%$ for the slow rusting check Saar. A total of 34 accessions showed high ITs to at least one of the $20 \mathrm{P}$. triticina strains during the seedling stage in the greenhouse or mixed races in seedlings in fields but had FDS less than $60 \%$ in the adult-plant stage in fields in two years. These wheat accessions were considered as having adult-plant resistance (Table 6).

Markers specific to adult-plant resistance genes $\operatorname{Lr} 34$ and $L r 46$ were used to assess the 118 wheat accessions. Among the 34 adult-plant resistance accessions, 14 accessions had the $L r 34$ associated allele ( $150 \mathrm{bp}$ ) of csLV34, and 16 had the $\mathrm{Lr} 46$ associated allele (520 bp) of csLV46G22. The postulated Lr34 carriers had mean FDS values of $11.9 \%$ in 2017, ranging from 1 to $35 \%$, and a mean of $20.4 \%$ in 2018 , ranging from 5 to $45 \%$. The postulated $L r 46$ carriers had mean FDS values of $7.9 \%$ in 2017, ranging from 1 to $15 \%$, and a mean of $7.8 \%$ in 2018, ranging from 5 to $15 \%$. Two cultivars, Shuwan 8 and Changwei 18, with $L r 34$ and $L r 46$ combination resistance, had mean FDS values of $1 \%$ and $15 \%$ in 2017 and both were 5\% in 2018.

Molecular assessment of genes. Gene-specific markers of $\operatorname{Lr} 9$, Lr10, Lr 19, Lr20, Lr24, and Lr37 were used to detect if these genes were present in the 118 wheat accessions. Because $\operatorname{Lr} 9, \operatorname{Lr} 19$, and $L r 24$ are resistant to all test $P$. triticina strains, the genes could not be postulated by phenotypes. The IT patterns of $\operatorname{Lr} 10$ and $\operatorname{Lr} 20$ on 20 strains were not found in 118 accessions; therefore, these two $L r$ genes also could not be postulated. $L r 37$ has been used in many breeding programs; it is important to know if $L r 37$ is present in this wheat collection. Marker Lr9_J13 produced a 1,100 bp allele in the Lr19 differential line, marker Lr10_Lrk10D produced a 282 bp band in the Lr10 differential line, marker Lr20_STS638 produced a 542 bp allele in the $L r 20$ differential line, marker Lr24_J09 produced a $310 \mathrm{bp}$ band in the Lr24 differential line, and marker VENTRIUP/ LN2 produced a 259 bp band in the $L r 37$ differential line, but all these markers did not produce any target band in any of the 118 wheat accessions, indicating $\operatorname{Lr} 9, \operatorname{Lr} 10, \operatorname{Lr} 20, \operatorname{Lr} 24$, and $\operatorname{Lr} 37$ are absent in these accessions. Marker Lr19_SCS265 having a 512 bp allele specifically associated with the $\operatorname{Lr} 19$ gene and a null allele when Lr19 was absent, and Lr19_SCS253 having a 736 bp allele when Lr19 was absent and a null allele when $\operatorname{Lr} 19$ was present were used to test the wheat accessions. Only a 736 bp allele was detected in all accessions and none of the accessions had a $512 \mathrm{bp}$ allele, indicating that $L r 19$ is not present in these accessions.

\section{Discussion}

The gene postulation approach can quickly identify the genes present in wheat cultivars with diverse genetic backgrounds and is widely used for identification of leaf rust resistance genes among the wheat lines (Gebrewahid et al. 2017; Kolmer 2003; Kolmer et al. 2013; Randhawa et al. 2016; Singh et al. 1999; Yuan et al. 2007; Zhang et al. 2019). In the present study, we postulated four seedling resistance genes $(L r 1, L r 26, L r 33$, and $L r 45)$ in 22 out of 118 wheat accessions. However, the genes present in other cultivars could not be postulated because of the nonmatching virulence patterns with any of the $L r$ reference lines. In these cases, more $P$. triticina races of diverse virulence phenotypes and/or reference lines with other $L r$ genes should be used to postulate the genes.

Molecular markers provided a more efficient and economical approach for gene detection. However, not all resistance genes have closely linked markers, and the accuracy of linked markers in predicting the presence of a target gene also depends on the linkage distance. In the study, closely linked markers for 10 genes were used to detect the presence of the genes. Results showed that these markers are stable and robust and can be well used for gene detection. Not all the genes contained good markers used in gene detection, however. In this case, it is necessary to develop more closely linked gene markers. In the study, two methods are used to verify each other, which shows the reliability of the results. The identification of $L r l$ and $L r 26$ using molecular markers is consistent with the results obtained by gene postulation.

Lrl was first reported in Malakoff (Mains et al. 1926) and designated as $L r l$ in 1946 (Ausemus et al. 1946). $L r l$ was widely present in bread wheats (Gebrewahid et al. 2017; Singh et al. 1999; Yuan et al. 2007). In the present study, $\operatorname{Lrl}$ was found in three cultivars, Luzhan 1, Taishan 1, and Linfen 10, and one improved germplasm. Analysis of their pedigree showed that all three cultivars have Bima 4 in their pedigrees (Table 1). The resistance of $\mathrm{Lrl}$ in these three cultivars is likely derived from Bima 4.

Lr26 was originated from rye (Secale cereale $\mathrm{L}$.) chromosome arm $1 \mathrm{RS}$ and present in wheat carrying a translocation of $1 \mathrm{BL} / 1 \mathrm{RS}$. In addition to carrying resistance to leaf rust, this translocation also has resistance to stem rust $(\operatorname{Sr} 31)$, stripe rust $(\operatorname{Yr} 9)$, and powdery mildew $(P m 8)$, and other good yield traits such as higher harvest index, spikes per square meter, thousand-kernel weight, and grain volume weight (Villareal et al. 2006).Cultivars Lovrin 10, Lovrin 13, Pedgornaia 2, Kavkaz, and Neuzucht carrying this translocation were introduced to breeding programs in China in the 1970s (He et al. 2001), leading to a high frequency of $L r 26$ in Chinese wheat cultivars ( $\mathrm{Li}$ et al. 2010; Zhou et al. 2004). In this study, Lr26 was found in 12 wheat cultivars. The cultivars carrying $L r 26$ resistance have either Lovrin 10, Lovrin 13, or Orofen in their pedigrees (Table 1). Lovrin 10 and Lovrin 13 carry Lr26 (McIntosh et al. 1995; Zhuang 2003). The Lr26 resistance in Beijing 8694 and Jingzhou HXB756-16 is likely derived from Lovirn 13, and the $L r 26$ resistance in Fengkang 7, Fengkang 10, Jimai 26, and Jingnong 79-63 from Lovrin 10. Li et al. (2009) reported Orofen has $L r 26$ resistance. The $L r 26$ resistance in Taishan 1, Jinmai 33, Simai 2, Jinghua 1, and Jingchun 70-5321 is probably derived from Orofen.

Lr33 resistance was originally identified from a Chinese wheat germplasm PI 58548, and two other wheat germplasms, PI 268454 from Afghanistan and PI 268316 from Iran (Dyck 1977, 1987). Lr33 resistance was also postulated in a global collection with 15 P. triticina strains (Chen and Wang 1997). This gene is rarely found in current Chinese wheat cultivars (Gebrewahid et al. 2017; Li et al. 2010; Singh et al. 1999; Yuan et al. 2007). In this study, Lr33 was postulated in two germplasms, PI 660067 and PI 660113. The resistance donor of PI 660113 is a Chinese cultivar Tianxuan 15 (PI479242), and the donor of PI 660067 is an Ethiopian landrace PI 480294 (Wang et al. 2012). Since Lr33 is not effective to the majority of the current prevalent $P$. triticina races in China, this gene has not been used in the current Chinese wheat breeding programs.

$L r 45$ resistance originated from rye and the $L r 45$ gene was located on the translocation T2AS-3RS.2RL (McIntosh et al. 1995). Lr45 has high level resistance in both seedling and adult plant stages to leaf rust, but the utilization in breeding programs is limited since it was associated with agronomic deficiencies and not normally inherited (McIntosh et al. 1995). Three wheat accessions in the present study 


\begin{tabular}{|c|c|c|c|c|c|c|c|c|c|c|c|c|c|c|c|c|c|c|c|c|c|c|}
\hline \multirow[b]{3}{*}{ Line no. ${ }^{\mathbf{b}}$} & \multirow{3}{*}{$\begin{array}{c}\text { Resistance } \\
\text { type }^{c}\end{array}$} & \multirow[b]{3}{*}{$L r$ genes } & \multicolumn{20}{|c|}{ Infection types ${ }^{a}$} \\
\hline & & & КH & TH & PH & FC & $\mathbf{P H}$ & PH & $\mathbf{P H}$ & TH & FHJ & FHJ & FHJ & FHJ & FHJ & FHJ & FGJ & FGJ & FHS & FHS & FHJ & FHJ \\
\hline & & & JS & TS & SQ & JS & JS & TS & JQ & ND & Q-1 & Q-2 & Q-3 & Q-4 & Q-5 & Q-6 & Q-1 & Q-2 & Q-1 & Q-2 & S-1 & S-2 \\
\hline 1 & & $\mathrm{~N}^{\mathrm{d}}$ & 4 & 4 & 4 & $3+$ & $3+$ & 4 & $3+$ & 4 & 4 & $3+$ & $3+$ & $3+$ & 3 & 4 & $3+$ & $3+$ & $3+$ & $3+$ & 4 & $3+$ \\
\hline 2 & & $++^{e}$ & 3 & 3 & 2 & $; 1$ & $3,3 \mathrm{c}$ & $3+$ & 2 & 3 & ; & 1 & 3 & 3 & 3 & 3 & 2 & 2 & 1 & 13 & 2 & 2 \\
\hline 3 & APR & $L r 34^{\mathrm{f}}$ & $3+$ & $3+$ & 4 & $3+$ & 3 & 3 & 3 & $3+$ & 3 & $3+$ & 3 & 3 & 3 & 3 & 3 & 3 & 3 & 3 & $3+$ & 3 \\
\hline 4 & APR & $L r 34^{\mathrm{f}}$ & 4 & $3+$ & $3+$ & 3 & $3+$ & $3+$ & $3+$ & $3+$ & $3+$ & $3+$ & $3+$ & $3+$ & 3 & $3+$ & 3 & $3+$ & $3+$ & $3+$ & $3+$ & $3+$ \\
\hline 5 & & $\mathrm{~N}$ & $3+$ & $3+$ & 4 & 3 & $3+$ & $3+$ & $3+$ & 3 & $3+$ & 3 & $3+$ & 3 & 3 & $3+$ & $3+$ & $3+$ & $3+$ & $3+$ & 4 & 3 \\
\hline 6 & & $\mathrm{~N}$ & $3+$ & 4 & 4 & 3 & $3+$ & $3+$ & 3 & $3+$ & 4 & 3 & $3+$ & $3+$ & $3+$ & 3 & $3+$ & $3+$ & $3+$ & $3+$ & $3+$ & $3+$ \\
\hline 7 & APR & $\mathrm{N}$ & 4 & 3 & 4 & $3+$ & $3+$ & 4 & 3 & $3+$ & $3+$ & $3+$ & $3+$ & $3+$ & 4 & 4 & 3 & 3 & $3+$ & 4 & $3+$ & $3+$ \\
\hline 8 & ASR & $\operatorname{Lr} 26^{\mathrm{g}},+$ & $2+$ & $2+$ & 3 & 3 & $3+$ & $3+$ & 1 & 3 & 3 & $3+$ & 3 & 3 & 3 & $3+$ & $;, 1$ & 1 & $3+$ & $3+$ & 4 & 3 \\
\hline 9 & & $\mathrm{~N}$ & $3+$ & 3 & 3 & $3+$ & 3 & 3 & $3+$ & 3 & 3 & 3 & $3+$ & $3+$ & 3 & 3 & $3+$ & 3 & 3 & $3+$ & 3 & 3 \\
\hline 10 & APR & $\operatorname{Lr} 46^{\mathrm{f}}$ & 4 & $3+$ & 4 & $3+$ & 4 & $3+$ & $3+$ & $3+$ & 4 & 4 & $3+$ & $3+$ & $3+$ & $3+$ & 3 & $3+$ & $3+$ & $3+$ & $3+$ & $3+$ \\
\hline 11 & & + & $3+$ & $3+$ & $3+$ & $3+$ & $3+$ & $3+$ & $3+$ & $3+$ & 3 & $3+$ & $3+$ & 3 & 1 & 4 & $3+$ & 4 & 3 & $3+$ & 4 & $3+$ \\
\hline 12 & & + & $3+$ & $3+$ & $3+$ & $3+$ & $3+$ & 4 & $3+$ & 4 & 4 & $3+$ & $3+$ & $3+$ & 1 & $3+$ & $3+$ & 4 & 3 & $3+$ & $3+$ & 3 \\
\hline 13 & APR & $\operatorname{Lr} 34^{\mathrm{f}},+$ & ; & $3+$ & 3 & 2,3 & 3 & 2,3 & 3 & 3 & 3 & 2,3 & 2,3 & $2,3+$ & 2,3 & 2,3 & 2,3 & 3 & 1,3 & $2+, 3+$ & 3 & 3 \\
\hline 14 & & $\mathrm{~N}$ & 3 & 4 & 4 & $3+$ & $3+$ & $3+$ & $3+$ & $3+$ & 4 & 3 & $3+$ & 3 & $3+$ & 4 & 3 & $3+$ & 3 & 3 & $3+$ & 3 \\
\hline 15 & APR & $\operatorname{Lr} 34^{\mathrm{f}}$ & $3+$ & $3+$ & $3+$ & $3+$ & $2,3+$ & $3+$ & $3+$ & $3+$ & 4 & $3+$ & 4 & $3+$ & 4 & 4 & 4 & 3 & 3 & 4 & 4 & $3+$ \\
\hline 16 & ASRAPR & $\operatorname{Lr} 1^{\mathrm{g}}, \operatorname{Lr} 46^{\mathrm{f}},+$ & ; & 3 & 1 & ; & 2 & 3 & 2 & 3 & ; & ; & ; & ; & 1 & $; 1$ & ; & ; & ; & ; &,, 1 & ; \\
\hline 17 & ASR & $\operatorname{Lr} 1^{\mathrm{g}}, \operatorname{Lr} 26^{\mathrm{g}},+$ & ; & 4 & ; & ; & 2 & $3+$ & 3 & 3 & ; & ; & ; & ; & 1 & $; 1$ & ; & ; &, 1 & ; & 1 & ; \\
\hline 18 & APR & $L r 34^{\mathrm{f}}, L r 46^{\mathrm{f}},+$ & $3+$ & $3+$ & 3 & $2,3+$ & 3 & 3 & $3+$ & 3 & 1 & $2,3+$ & 3 & 2,3 & 3 & 3 & 3 & 3 & $3+$ & $3+$ & $3+$ & 3 \\
\hline 19 & APR & $\operatorname{Lr} 46^{\mathrm{f}}$ & $3+$ & 4 & 4 & $3+$ & 4 & $3+$ & $3+$ & $3+$ & 4 & $3+$ & $3+$ & 3 & $3+$ & 4 & 4 & $3+$ & $3+$ & 3 & 4 & 3 \\
\hline 20 & & $\mathrm{~N}$ & $3+$ & $3+$ & 3 & 3 & $3+$ & $3+$ & $3+$ & $3+$ & 3 & $3+$ & $3+$ & $3+$ & $3+$ & $3+$ & 3 & $3+$ & 3 & $3+$ & $3+$ & 3 \\
\hline 21 & & $\mathrm{~N}$ & $3+$ & 4 & 3 & 3 & $3+$ & $3+$ & $3+$ & 4 & 3 & 3 & 3 & 3 & 3 & $3+$ & 3 & 3 & 3 & 3 & 3 & 3 \\
\hline 22 & & $\mathrm{~N}$ & 3 & 3 & 3 & 3 & $2,3+$ & 3 & $3+$ & $3+$ & 3 & 3 & 3 & $2,3+$ & $3+$ & 3 & $3+$ & 3 & 3 & $3+$ & 3 & 3 \\
\hline 23 & APR & $\operatorname{Lr} 34^{\mathrm{f}}$ & 3 & $3+$ & 3 & 3 & 3 & $3+$ & $3+$ & $3+$ & 3 & 3 & 3 & 3 & 3 & 3 & 3 & 3 & 3 & 3 & $3+$ & 3 \\
\hline 24 & ASRAPR & $\operatorname{LrI}^{\mathrm{g}}, \operatorname{Lr} 46^{\mathrm{f}},+$ & ; & 4 & $3 \mathrm{c}$ & ; & $3+$ & $3+$ & 4 & 3 & 1 & $; 1$ & 1 & ; & $;, 1$ & 1 & 2 & $; 1$ & 1 & $; 1$ & ; & ; \\
\hline 25 & & + & 4 & $2+$ & $3+$ & $3+$ & $3+$ & $3+$ & $3+$ & 4 & 3 & $3+$ & $3+$ & $3+$ & 3 & $3+$ & 3 & 4 & 3 & $3+$ & $3+$ & 3 \\
\hline 26 & ASR & $\operatorname{Lr} 26^{\mathrm{g}}$ & 4 & $3-$ & 4 & 4 & $3+$ & $3+$ & 4 & $3+$ & 4 & $3+$ & 4 & $3+$ & $3+$ & 3 & 1 & 1 & $3+$ & 3 & $3+$ & $3+$ \\
\hline 27 & ASR & $\operatorname{Lr} 26^{\mathrm{g}},+$ & 4 & $2+$ & $3+$ & 3 & $3+$ & $3+$ & 4 & $3+$ & $3+$ & 4 & $3+$ & 3 & 1 & 3 & 1 & 1 & $3+$ & 3 & $3+$ & 3 \\
\hline 28 & APR & $\operatorname{Lr} 34^{\mathrm{f}}$ & 4 & 3 & $3+$ & $3+$ & $3+$ & $3+$ & $3,3 \mathrm{c}$ & $3+$ & 4 & $3+$ & 3 & 3 & 3 & $3+$ & 3 & 3 & $3+$ & $3+$ & $3+$ & $3+$ \\
\hline 29 & ASR & $\operatorname{Lr} 26^{\mathrm{g}},+$ & $3+$ & $2+$ & $3+$ & 3 & $3+$ & 4 & $2,3+$ & $3+$ & 3 & $3+$ & 3 & $2+, 3+$ & 3 & 3 & 1 & 1 & $3+$ & $3+$ & $3+$ & $3-$ \\
\hline 30 & ASR & $\operatorname{Lr} 26^{\mathrm{g}}$ & $3+$ & 3 & $3+$ & $3+$ & $3+$ & 4 & $3+$ & $3+$ & $3+$ & 3 & 4 & 3 & 3 & $3+$ & 1 & 1 & 3 & $3+$ & $3+$ & 3 \\
\hline 31 & APR & $L r 46^{\mathrm{f}},+$ & 1 & 4 & 2 & 3 & $3+$ & $3+$ & 3 & $3+$ & 2 & 2 & 3 & 3 & 3 & 3 & 2 & 1 & 3 & 3 & 2 & $; 1$ \\
\hline 32 & & + & 3 & 3 & 4 & 23 & $3+$ & 4 & 3 & 3 & 2 & 2 & 3 & $3,2+$ & $2+$ & $3+$ & 2 & 3 & 2 & 3 & 3 & $3-$ \\
\hline 33 & ASR & $\operatorname{Lr} 26^{\mathrm{g}}$ & $3+$ & 3 & 4 & $3+$ & $3+$ & 4 & 3 & 3 & 3 & $3+$ & $3+$ & 3 & 3 & $3+$ & 1 & 1 & 3 & 3 & 4 & 3 \\
\hline 34 & APR & $L r 46^{\mathrm{f}}$ & $3+$ & 3 & 4 & 3 & 3 & 4 & $3+$ & 3 & $3+$ & $3+$ & $3+$ & 3 & 3 & $3+$ & $3+$ & 3 & 3 & $3+$ & $3+$ & $3+$ \\
\hline 35 & APR & $L r 46^{\mathrm{f}}$ & 4 & 3 & 4 & 3 & $3+$ & $3+$ & 4 & $3+$ & $3+$ & 4 & $3+$ & 4 & 13 & $3+$ & $3+$ & $3+$ & 3 & $3+$ & $3+$ & 4 \\
\hline 36 & & + & 3 & $3+$ & 4 & 2 & $3+$ & 4 & $3+$ & $3+$ & $2+$ & 3 & $2,3+$ & $3+$ & 3,1 & $3+$ & 2 & $3+$ & $3+$ & $3+$ & 3 & $; 3$ \\
\hline 37 & APR & $\operatorname{Lr} 34^{\mathrm{f}},+$ & 3 & $3+$ & 4 & 3 & $3+$ & 4 & 4 & 4 & 3 & 3 & 2,3 & $3+$ & 1 & $3+$ & 3 & $3+$ & 2,3 & $3+$ & $3+$ & 3, \\
\hline 38 & APR & $L r 46^{\mathrm{f}}$ & 3 & 3 & 3 & 3 & 3 & 3 & 3 & 3 & 3 & 3 & 3 & 3 & 3 & 3 & 3 & 3 & 4 & 3 & 3 & 3 \\
\hline 39 & & + & 2 & 3 & 3 & 3 & $2,3+$ & 3 & 3 & 3 & 3 & 3 & 3 & 3 & 3 & 3 & 3 & 3 & 2,3 & 3 & 3 & 1,3 \\
\hline 40 & APR & $\operatorname{Lr} 34^{\mathrm{f}}, \operatorname{Lr} 46^{\mathrm{f}},+$ & 1 & 3 & 3 & 3 & 3 & $3+$ & 3 & $3+$ & $3-$ & 3 & 13 & 3 & 1 & 3 & 1,3 & $3+$ & 1,3 & 1,3 & $1,3+$ & 2 \\
\hline 41 & APR & $\operatorname{Lr} 46^{\mathrm{f}}$ & 3 & $3+$ & $3+$ & 3 & $3+$ & $3+$ & $3+$ & $3+$ & 3 & $3+$ & 3 & 3 & 3 & $3+$ & 3 & 3,1 & 3,1 & $3+$ & $3+$ & $; 3$ \\
\hline 42 & APR & $\operatorname{Lr} 34^{\mathrm{f}},+$ & 2 & 3 & 1 & 1 & 2 & $3+$ & 3 & 3 & 3 & 3 & 3 & 1 & 3 & 2 & 2 & 1 & 3 & 3 & 1 & ; \\
\hline 43 & & + & $3+$ & 4 & 4 & 3 & $3+$ & 4 & 3 & 3 & $3+$ & $3+$ & $3+$ & 4 & 1 & 3 & $3+$ & $3+$ & $3+$ & $3+$ & 4 & 4 \\
\hline 44 & APR & $\mathrm{N}$ & 4 & 4 & 3 & 3 & 4 & 4 & 4 & $3+$ & $3+$ & $3+$ & 4 & $3+$ & $3+$ & $3+$ & 3 & $3+$ & 3 & $3+$ & $3+$ & 3 \\
\hline 45 & APR & $\operatorname{Lr} 34^{\mathrm{f}}$ & $3+$ & 4 & 4 & 3 & 4 & $3+$ & $3+$ & 4 & 3 & $3+$ & $3+$ & $3+$ & $3+$ & 3 & 3 & 3 & 3 & $3+$ & $3+$ & 3- \\
\hline 46 & & $\mathrm{~N}$ & $3+$ & 4 & $3+$ & 3 & $3+$ & 3 & $3+$ & 3 & $3+$ & 3 & $3+$ & 3 & $3+$ & $3+$ & 1,3 & $3+$ & 3 & $3+$ & $3+$ & $3+$ \\
\hline 47 & ASR & $\operatorname{Lr} 26^{\mathrm{g}}$ & 3 & $3+$ & $3+$ & 3 & 3 & $3+$ & 4 & $3+$ & 3 & $3+$ & 3 & 3 & $3+$ & 3 & 1 & 1 & 3 & $3+$ & $3+$ & 3 \\
\hline 48 & & $\mathrm{~N}$ & $3+$ & $3+$ & $3+$ & 3 & $3+$ & $3+$ & $3+$ & $3+$ & 3 & 3 & 3 & 3 & 3 & 3 & 3 & 3 & 3 & 3 & $3+$ & 3 \\
\hline 49 & APR & $L r 46^{\mathrm{f}},+$ & 3 & 3 & $3+$ & $3+$ & $3+$ & $3+$ & $3+$ & $3+$ & $3+$ & 1 & $1,3+$ & 2,3 & 1 & 3 & 1 & 1 & 3 & $3+$ & $1,3+$ & 3,1 \\
\hline 50 & APR & $\mathrm{N}$ & 3 & $3+$ & 4 & 3 & $3+$ & $3+$ & 4 & $3+$ & 3 & 3 & 3 & 3 & 3 & 3 & 3 & 3 & 3 & 3 & 3 & 3 \\
\hline 51 & & + & 3 & 4 & 4 & 3- & $3+$ & 4 & 4 & 4 & $3+$ & $3+$ & 3 & $3+$ & 1 & 3 & 3 & $3+$ & $3+$ & $3+$ & $3+$ & 3 \\
\hline 52 & ASR & $\operatorname{Lr} 26^{\mathrm{g}},+$ & $3+$ & $3+$ & $2,3+$ & 3,2 & $3+$ & $3+$ & 3 & 3 & 1,3 & $1,3+$ & ;,3+ & $1,3+$ & $3,1+$ & 1,3 & 1 & 1 & 1 & 1,2 & 2 & 3 \\
\hline 53 & & + & 1 & 3 & 3 & 3 & $3+$ & $3+$ & $3+$ & 4 & 3 & 3 & 1,3 & $1,3+$ & $2+$ & 3 & $2,2+$ & 3 & 2 & $3,3 \mathrm{c}$ & 2,3 & 2 \\
\hline 54 & & $\mathrm{~N}$ & $3+$ & $3+$ & $3+$ & $3+$ & $3+$ & 4 & 3 & $3+$ & $3+$ & $3+$ & $3+$ & $3+$ & 3 & 3 & 3 & $3+$ & 3 & $3+$ & 4 & $3+$ \\
\hline 55 & & + & 3 & 3 & 3 & 1 & $3+$ & 4 & 3 & $3+$ & 1 & 3 & $3+$ & $3+$ & 3 & 3 & 3 & $; 1$ & 2 & $3+$ & 2 & $3+$ \\
\hline
\end{tabular}

a According to the 0 to 4 Stakman scale. $0=$ no flecks or uredinia, $;=$ hypersensitive flecks, $1=$ small uredinia with necrosis, $2=$ small uredinia with chlorosis, $3=$ moderate size uredinia, 4 = large uredinia, + indicates slightly larger uredinia, - indicates slightly smaller uredinia, $\mathrm{C}$ indicates more chlorosis than normal for the infection type.

${ }^{\mathrm{b}}$ Line numbers correspond to those in Table 1.

${ }^{\mathrm{c}}$ Resistance type: APR, adult-plant resistance; ASR, all-stage resistance.

d N: no $L r$ gene postulated.

e +: unidentified $L r$ gene.

${ }^{\mathrm{f}}$ Detection of $\mathrm{Lr}$ genes based on molecular marker.

g Postulation of $L r$ genes based on gene postulation and molecular marker.

h Postulation of $L r$ genes based on gene postulation. 
Infection types $^{\mathrm{a}}$

\begin{tabular}{|c|c|c|c|c|c|c|c|c|c|c|c|c|c|c|c|c|c|c|c|c|c|c|}
\hline \multirow{3}{*}{ Line no. ${ }^{b}$} & \multirow{3}{*}{$\begin{array}{c}\text { Resistance } \\
\text { type }\end{array}$} & \multirow[b]{3}{*}{$L r$ genes } & \multirow{3}{*}{$\overline{\mathrm{KH}}$} & \multirow{3}{*}{$\frac{\mathrm{TH}}{\mathrm{TS}}$} & & & & & & & & & & & & & & & & & & \\
\hline & & & & & $\underline{\mathbf{P H}}$ & FC & $\underline{\mathbf{P H}}$ & PH & $\underline{\mathbf{P H}}$ & TH & FHJ & FHJ & FHJ & FHJ & FHJ & FHJ & FGJ & FGJ & FHS & FHS & FHJ & FHJ \\
\hline & & & & & SQ & $\overline{\text { JS }}$ & $\overline{\mathbf{J S}}$ & TS & $\overline{\mathrm{JQ}}$ & ND & Q-1 & $\overline{Q-2}$ & $\overline{Q-3}$ & $\overline{Q-4}$ & $\overline{Q-5}$ & $\overline{Q-6}$ & $\overline{Q-1}$ & $\overline{Q-2}$ & $\overline{Q-1}$ & $\overline{Q-2}$ & $S-1$ & $S-2$ \\
\hline 56 & & + & 3 & $3+$ & $2+$ & 3 & 3 & 2 & 4 & $3+$ & ; & 3 & $3+$ & 3 & 2 & 2,3 & 3 & $3+$ & 3 & $3+$ & 3 & $\overline{1,3}$ \\
\hline 57 & & $\mathrm{~N}$ & 3 & 4 & $3+$ & $3+$ & $3+$ & 4 & $3+$ & $3+$ & $3+$ & 3 & $3+$ & 3 & $3+$ & 3 & 3 & 3 & 3 & 3 & $3+$ & 3 \\
\hline 58 & & + & 3 & $3+$ & $3+$ & 3,1 & $3+$ & $3+$ & 3 & $3+$ & $3+$ & 2 & 3 & 3 & 3 & 3 & 3- & 3 & 3 & $3+$ & 3 & 3 \\
\hline 59 & APR & $L r 34^{\mathrm{f}}$ & 3 & $3+$ & 4 & $3+$ & $3+$ & $3+$ & $3+$ & 3 & $3+$ & $3+$ & $3+$ & $3+$ & 3 & 3 & 3 & 3 & $3+$ & $3+$ & 3 & 3 \\
\hline 60 & & + & $3+$ & 2,3 & 3 & $3+$ & 2,3 & 4 & 4 & 3 & 2,3 & 3 & $3+$ & 3 & 1,2 & $2,3+$ & 1 & 1 & $2,3+$ & $3+$ & 3 & 1 \\
\hline 61 & APR & $\mathrm{N}$ & $3+$ & 4 & $3+$ & 3 & $3+$ & $3+$ & 4 & 3 & 3 & $3+$ & $3+$ & $3+$ & 3 & 4 & $3+$ & 3 & 3 & $3+$ & 3 & 3 \\
\hline 62 & & + & 4 & 4 & $3+$ & 4 & $3+$ & $3+$ & $3+$ & $3+$ & 4 & $3+$ & $3+$ & $3+$ & 4 & 1 & 1 & 1 & $3+$ & 3 & $3+$ & 3 \\
\hline 63 & & $\mathrm{~N}$ & 3 & 4 & 3 & 4 & $3+$ & 4 & $3+$ & $3+$ & 4 & 3 & $3+$ & $3+$ & 3 & $3+$ & 3 & 3 & $3+$ & $3+$ & $3+$ & 3 \\
\hline 64 & & + & 3 & 2 & $3+$ & $3+$ & 3 & 4 & $3+$ & 3 & 3 & 3 & $3+$ & 3 & 3 & $3+$ & 3 & $3+$ & 3 & $3+$ & 3 & $3+$ \\
\hline 65 & & $\mathrm{~N}$ & 3 & 3 & $3+$ & 3 & $3+$ & $3+$ & $3+$ & 3 & $3+$ & 1,3 & $3+$ & $3+$ & $3,3 \mathrm{c}$ & $3+$ & 3 & 3 & 3 & $3+$ & 3 & $3+$ \\
\hline 66 & & + & 3 & 2 & $2+$ & 1 & $3+$ & 4 & $2,3+$ & $3+$ & $3+$ & $1+$ & $3+$ & 1 & 3 & 3 & 3 & $; 1$ & 3 & $3+$ & 3 & $3+$ \\
\hline 67 & APR & $\mathrm{N}$ & 3 & 4 & $3+$ & $3+$ & $3+$ & 4 & 4 & $3+$ & $3+$ & $3+$ & $3+$ & $3+$ & $3+$ & $3+$ & 3 & 3 & $3+$ & $3+$ & $3+$ & $3+$ \\
\hline 68 & & + & 4 & 1 & 4 & 3 & $3+$ & $3+$ & 4 & 3 & 3 & 3 & $3+$ & 3 & $3+$ & 4 & 3 & 3 & $3+$ & $3+$ & $3+$ & $2+, 3-$ \\
\hline 69 & ASR & $\operatorname{Lr} 26^{\mathrm{g}},+$ & $3+$ & $2+$ & $3+$ & 3 & $3+$ & $3+$ & 4 & $3+$ & $3+$ & 3 & $3+$ & $2+, 3+$ & 2 & $3 c$ & 1 & 1 & $3+$ & 3 & $3+$ & 3 \\
\hline 70 & & + & $3+$ & $1+$ & $3+$ & 3 & 3 & $3+$ & 3 & $3+$ & $3+$ & 3 & $3+$ & 3 & $3+$ & $3+$ & 3 & 3 & 3 & $3+$ & $3+$ & 3 \\
\hline 71 & APR & $\mathrm{N}$ & 4 & 4 & 4 & $3+$ & 3 & $3+$ & $3+$ & $3+$ & 4 & $3+$ & $3+$ & 4 & $3+$ & $3+$ & $3+$ & 3 & $3+$ & $3+$ & $3+$ & 3 \\
\hline 72 & & $\mathrm{~N}$ & 4 & 4 & $3+$ & 3 & 3 & 4 & $3+$ & $3+$ & 4 & 4 & $3+$ & 4 & $3+$ & 3 & $3+$ & 4 & 3 & 3 & $3+$ & 3 \\
\hline 73 & & + & 3 & 3- & 3 & 3 & $2,3+$ & 3 & $3+$ & 2,3 & $3+$ & 3 & 3 & 2 & 2,3 & 2,3 & 3- & 3 & 3 & 3 & 3- & 3 \\
\hline 74 & & + & $3+$ & $3+$ & 4 & 3 & $3+$ & 4 & 4 & $3+$ & 3 & 3 & 4 & $3+$ & 2 & 3 & 3 & 3 & 3 & $3+$ & $3+$ & $2+$ \\
\hline 75 & & $\mathrm{~N}$ & 4 & 4 & 4 & $3+$ & $3+$ & 4 & 4 & $3+$ & $3+$ & $3+$ & 4 & 3 & $3+$ & $3+$ & $3+$ & $3+$ & 3 & $3+$ & $3+$ & 3 \\
\hline 76 & & $\mathrm{~N}$ & 4 & 4 & 4 & 4 & 4 & 4 & $3+$ & $3+$ & 3 & 4 & $3+$ & $3+$ & $3+$ & $3+$ & 4 & $3+$ & $3+$ & $3+$ & 4 & 3 \\
\hline 77 & & $\mathrm{~N}$ & 4 & 4 & $3+$ & 4 & 4 & 4 & $3+$ & $3+$ & $3+$ & 4 & $3+$ & $3+$ & $3+$ & $3+$ & $3+$ & 4 & $3+$ & $3+$ & $3+$ & 3 \\
\hline 78 & & $\mathrm{~N}$ & $3+$ & 4 & $3+$ & 4 & $3+$ & 4 & $3+$ & $3+$ & 3 & $3+$ & 3 & $3+$ & $3+$ & $3+$ & 3 & 4 & $3+$ & $3+$ & $3+$ & 3 \\
\hline 79 & & $\mathrm{~N}$ & 3 & $3+$ & 3 & $3+$ & $23+$ & 3 & 3 & $23+$ & $3+$ & $3+$ & 3 & $3+$ & 3 & $3+$ & 3 & 3 & $3+$ & $3+$ & 3 & 3 \\
\hline 80 & & $\mathrm{~N}$ & $3+$ & 4 & $3+$ & 3 & 3 & $3+$ & $3+$ & $3+$ & 3 & $3+$ & $3+$ & $3+$ & $3+$ & $3+$ & 3 & $3+$ & $3+$ & $3+$ & $3+$ & 3 \\
\hline 81 & & $\mathrm{~N}$ & 3 & $3+$ & $3+$ & 3 & $3+$ & $3+$ & 3 & 3 & 3 & 3 & $3+$ & 2,3 & 3 & 3 & 3 & $3+$ & 3 & $3+$ & $3+$ & 3 \\
\hline 82 & & $\mathrm{~N}$ & $3+$ & $3+$ & 4 & $3+$ & $3+$ & 4 & 4 & $3+$ & $3+$ & $3+$ & $3+$ & $3+$ & 4 & $3+$ & 3 & $3+$ & 3 & $3+$ & $3+$ & $3+$ \\
\hline 83 & & + & $3+$ & 2 & 4 & $3+$ & $3+$ & 4 & 4 & 3 & 3 & 3 & $3+$ & $3+$ & 4 & $3+$ & 3 & $3+$ & 3 & $3+$ & 4 & 3- \\
\hline 84 & & + & 3 & 4 & 1 & 2 & 2 & 4 & 3 & 3 & $3+$ & 2 & 3 & 3 & $3+$ & 2 & 2 & $3 \mathrm{c}$ & 1 & $;, 1$ & 3 & 3 \\
\hline 85 & ASR & $L r 45^{\mathrm{h}}$ & $3+$ & 4 & $3+$ & 2 & 4 & $3+$ & 4 & 3 & $3+$ & 3 & 4 & $3+$ & $3+$ & $3+$ & 3 & 3 & 3 & $3+$ & 3 & 3 \\
\hline 86 & & + & $3+$ & $3+$ & 2 & 2 & 3 & 2 & 4 & $3+$ & 3 & 2 & 2 & 2,3 & $3+$ & 3 & 3 & 3 & 3 & $3+$ & 3 & $3 c$ \\
\hline 87 & & + & 3 & $2,3+$ & 3 & $2+$ & $3+$ & $3+$ & 2 & 3 & $3+$ & 2 & 3 & 3 & 3 & $3+$ & 1,3 & 3 & $3+$ & 3 & $3+$ & 3 \\
\hline 88 & & + & 3 & $1+$ & 3 & $3+$ & 3 & $3+$ & 2 & 3 & 3 & 3 & $3+$ & 3 & 2 & 3 & 3 & $3+$ & 3 & 3 & 3 & 3 \\
\hline 89 & & + & 4 & $3+$ & 3 & $3+$ & 4 & $3+$ & $2+$ & 3 & 3 & 2,3 & 4 & $3+$ & 3 & 3 & 3 & $3+$ & 3 & 3 & $3+$ & 3 \\
\hline 90 & & + & $3+$ & 2,3 & 3 & 3 & 4 & 4 & $3+$ & $3+$ & 3 & 3 & $3+, 2+$ & 2 & 3 & 3 & 2 & 3 & 3 & 3 & 4 & 3 \\
\hline 91 & ASR & $L r 45^{\mathrm{h}}$ & 4 & $3+$ & $3+$ & 2 & $3+$ & 4 & $3+$ & 3 & $3+$ & 3 & $3+$ & $3+$ & $3+$ & 3 & 3 & $3+$ & 3 & 3 & 4 & $3+$ \\
\hline 92 & & + & 3 & 1 & 3 & 3 & 3 & ; $3+$ & $3+$ & $3+$ & $3+$ & $3+$ & $3+$ & $3+$ & $3+$ & 3 & 3 & 3 & $3+$ & $3+$ & 3 & 3 \\
\hline 93 & APR & $L r 34^{\mathrm{f}}$ & 3 & 4 & $3+$ & $3+$ & 3 & 4 & $3+$ & 4 & $3+$ & $3+$ & $3+$ & $3+$ & $3+$ & $3+$ & $3+$ & 3 & 3 & $3+$ & $3+$ & 3 \\
\hline 94 & & $\mathrm{~N}$ & $3+$ & 4 & $3+$ & 3 & 3 & 4 & $3+$ & 4 & $3+$ & $3+$ & $3+$ & $3+$ & 3 & $3+$ & $3+$ & 3 & 4 & $3+$ & $3+$ & 3 \\
\hline 95 & ASR & $\operatorname{Lr} 26^{\mathrm{g}},+$ & 3 & 4 & $3-$ & 3 & $2,3+$ & 4 & $3+$ & $3+$ & 3 & $3+$ & 2 & $3+$ & 3 & 3 & 1 & 1 & 3 & 3 & $3+$ & 3 \\
\hline 96 & & + & $1+$ & 2 & $2+$ & 3 & $3+$ & 3 & $3+$ & $3+$ & 1 & 3 & 3 & 3 & 3 & 3 & 1 & ; & 2 & 2 & 3 & 1 \\
\hline 97 & ASR & $L r 26^{\mathrm{g}},+$ & 3 & 1 & 3- & 3 & $3+$ & $3+$ & $1,3+$ & 3 & 3 & 1 & 3 & 3 & 3 & $3+$ & $;, 1$ & 1 & $3+$ & $3+$ & 3 & 3 \\
\hline 98 & & $\mathrm{~N}$ & 3 & 3 & 3 & $3+$ & 3 & $3+$ & $3+$ & 3 & $3+$ & 3 & $3+$ & $3+$ & 3 & $3+$ & $3+$ & $3+$ & $3+$ & $3+$ & $3+$ & 3 \\
\hline 99 & & $\mathrm{~N}$ & $3+$ & $3+$ & $3+$ & 3 & $3+$ & 4 & $3+$ & $3+$ & 4 & $3+$ & $3+$ & $3+$ & $3+$ & $3+$ & $3+$ & 3 & 4 & $3+$ & 3 & 3 \\
\hline 100 & & + & 3 & 4 & 4 & 3 & $3+$ & 4 & 4 & 4 & 4 & 3 & $3+$ & $3+$ & $3+$ & 3 & $3+$ & 3 & $3+$ & 3 & 3 & 2 \\
\hline 101 & ASR & $L r 33^{\mathrm{h}}$ & $3+$ & 4 & $3+$ & 2 & 2 & 4 & 3 & $3+$ & 4 & 4 & $3+$ & $3+$ & $3+$ & $3+$ & $3+$ & $3+$ & $3+$ & $3+$ & $3+$ & $3-$ \\
\hline 102 & & + & $3+$ & 2 & $3+$ & $2+$ & 1 & 4 & 2 & 3 & 2 & $3 c$ & $3+$ & $3+$ & 3 & $2+$ & $3 c$ & 3 & $3+$ & 3 & 3 & $2+$ \\
\hline 103 & & + & 3 & 1 & 2 & 2 & 1 & 3 & $2+$ & 3 & $3+$ & 3 & $3+$ & $3 c$ & $3+$ & $2+$ & 3 & 3 & $3 c$ & $3 \mathrm{c}$ & 2 & 3 \\
\hline 104 & & $\mathrm{~N}$ & 3 & $3 c$ & 3 & $3+$ & 3 & $3+$ & 3 & 3 & 3 & $3+$ & $3+$ & $3+$ & $3+$ & $3+$ & 3 & 3 & $3+$ & $3+$ & $3+$ & 3 \\
\hline 105 & & + & 1 & 3 & $;, 1$ & 2 & $;, 1$ & 1 & 1 & 3 & 1 & ; & 2 & 3 & 3 & 1 & 2 & 1 & 2 & 1 & 2 & 1 \\
\hline 106 & ASR & $L r 45^{\mathrm{h}}$ & 3 & 4 & $3+$ & 2 & 3 & $3+$ & 3 & 3 & $3+$ & $3+$ & $3+$ & $3+$ & $3+$ & $3+$ & $3+$ & $3+$ & $3+$ & $3+$ & $3+$ & $3+$ \\
\hline 107 & & + & 3 & 1,3 & 2 & 2 & $\therefore 1$ & $1+$ & 3 & $3+$ & $2+$ & 3 & $3+$ & 3 & 2 & $3+$ & 2 & 1 & 2 & 2 & 2 & 2 \\
\hline 108 & & + & 2 & $3+$ & 2 & 3 & 3 & 3 & 2 & 3 & 3 & 1 & 3 & 3 & 2 & 3 & 2 & 3 & $3+$ & $3+$ & 2 & $1+$ \\
\hline 109 & & + & 4 & $2+$ & $3+$ & $3+$ & 3 & 4 & 4 & 4 & $3+$ & 3 & $3+$ & 3 & 3 & 3 & 3 & 3 & 3 & 3 & 3 & 3 \\
\hline 110 & APR & $L r 34^{\mathrm{f}}$ & $3+$ & 3 & $3+$ & 3 & 1,3 & 4 & $3+$ & 3 & $3+$ & 3 & $3+$ & 3 & 3 & 3 & $3-$ & 3 & 3 & 3 & 3 & 3- \\
\hline 111 & APR & $L r 46^{\mathrm{f}}$ & $3+$ & 4 & 4 & $3+$ & 3 & 4 & 4 & 4 & 4 & $3+$ & 4 & $3+$ & $3+$ & 4 & 3 & $3+$ & $3+$ & $3+$ & 3 & $3+$ \\
\hline 112 & & $\mathrm{~N}$ & 4 & $3+$ & 4 & 3 & 3 & 4 & $3+$ & $3+$ & 4 & $3+$ & $3+$ & $3+$ & $3+$ & 4 & 3 & $3+$ & $3+$ & $3+$ & 3 & 4 \\
\hline 113 & APR & $L r 46^{\mathrm{f}}$ & 4 & 4 & $3+$ & $3+$ & $3,2+$ & 4 & $3+$ & 3 & 4 & $3+$ & $3+$ & $3+$ & $3+$ & 4 & 3 & 3 & $3+$ & $3+$ & $3+$ & 4 \\
\hline 114 & ASRAPR & $L r 1^{\mathrm{g}}, L r 46^{\mathrm{f}}$ & 1 & $1+$ & 3 & $;, 1$ & 1 & 2 & 3- & 3 & 2 & 1 & 1 & 1 & 1 & 1 & $;, 1$ & 3 & 1 & 2 & 2 & 1 \\
\hline 115 & ASRAPR & $L r 33^{\mathrm{h}}, L r 46^{\mathrm{f}}$ & $3+$ & 4 & $3+$ & $2+$ & 2 & 3 & $3+$ & $3+$ & 4 & $3+$ & $3+$ & $3+$ & $3+$ & 4 & $3+$ & $3+$ & $3+$ & $3+$ & 3 & 3 \\
\hline 116 & & + & 1 & ; & ; & 3 & 3 & ; & $;, 1$ & 3 & 3 & 3 & 3 & 3 & 1 & 2 & 1 & ; & 3 & 3 & 1 & ; \\
\hline 117 & & + & 4 & $3+$ & 3 & 2 & 3 & $3+$ & 3 & 4 & 2 & 3 & 3 & 2 & 3,2 & 3 & 3 & $3+$ & 2 & $2+$ & 3 & 3 \\
\hline 118 & & + & $3+$ & 2 & 3 & $2+$ & 3 & $3+$ & 1,3 & $1,3+$ & 3 & 3 & $3+$ & $3 \mathrm{c}$ & 3 & 2 & $3+$ & $3+$ & 3 & $3 \mathrm{c}$ & 3 & $3,2+$ \\
\hline
\end{tabular}


were postulated carrying $\mathrm{Lr} 45$. In field adult plant tests, the three wheat accessions were resistant in 2017, and PI 660073 was resistant in 2018. Since this gene has good resistance to leaf rust, if using new genetic techniques breaks the genetic lag, this gene can be used for improvement of leaf rust resistance in wheat cultivars.

Lr34 is the first cloned slow rusting resistance gene, which confers resistance to leaf rust, stripe rust, stem rust, and powdery mildew. The resistance had been kept for more than 50 years (Lagudah et al. 2009). It is widely present in wheat worldwide (Kolmer et al. 2008; Singh et al. 2007). In their evaluation of a larger number of

Table 5. Analysis of variance of final disease severity (FDS) in 120 wheat genotypes, including slow rusting cultivar Saar and susceptible Zhengzhou 5389 checks, tested in the 2016 to 2018 growing seasons

\begin{tabular}{llrrrr}
\hline Parameter & Source of variation & df & \multicolumn{1}{c}{ MS $^{\mathbf{a}}$} & $\boldsymbol{F}$ value & \multicolumn{1}{c}{$\boldsymbol{P}$} \\
\hline FDS & Genotype & 119 & $1,463.6$ & $6.5^{\mathrm{b}}$ & $<0.0001$ \\
& Environment & 1 & $153,005.9$ & $674.6^{\mathrm{b}}$ & $<0.0001$ \\
& Replication & 1 & $12,350.5$ & 54.5 & 0.0601 \\
& Genotype*environment & 119 & 831.3 & $3.7^{\mathrm{b}}$ & $<0.0001$ \\
& Genotype*replication & 119 & 250.5 & 1.1 & 0.2924 \\
& Error & 119 & 226.8 & & \\
\hline
\end{tabular}

${ }^{\mathrm{a}} \mathrm{MS}=$ Mean square.

b Significant at 0.05 level of probability. global collections of wheat landraces, improved germplasms, and current and historic cultivars, Kolmer et al. (2008) found the Lr34 gene in modern wheat cultivars from North and South America, CIMMYT, Australia, China, and Russia, which can be tracked back to the cultivars Mentana, Ardito, Exchange, Frontana, and Chinese Spring. Chinese wheat landraces have a high frequency (30\%) of Lr34 (Kolmer et al. 2008). Yang et al. (2008) found 14 (6.1\%) commercial cultivars and 359 (85.1\%) landraces having the $L r 34$ allele, and $L r 34$ resistance in commercial cultivars was mostly from Nanda 2419, Ardito, or Xiannong 4 based on the pedigree. In this study, 14 accessions with $L r 34$ showed good resistance in field conditions. The Lr34 resistance in five Chinese cultivars (Jinghong 4, E'mai 9, Jinmai 20, Shuwan 8 , and Weidong 4) is likely derived from Nanda 2419 (Mentana) and Lr34 in Kechun 14 and Changwei 18 from Orofen, which are present in their pedigrees.

Lr46 was another important slow rusting resistance gene, first identified in a CIMMYT cultivar Pavon 76 and mapped on chromosome 1B (Singh et al. 1998; William et al. 2003). Lr46 resistance was reported in wheat cultivars from CIMMYT and other countries (Basnet et al. 2013; Calvo-Salazar et al. 2015; Lan et al. 2014, 2015; Lillemo et al. 2008; Ponce-Molina et al. 2018; Ren et al. 2017; Rosewarne et al. 2012). It has remained effective for almost 30 years (William et al. 2006). The locus of $L r 46$ cosegregated with Yr29 (William et al. 2003), Sr58 (Singh et al. 2013), and Pm39

Table 6. Infection types (ITs) of mixed Puccinia triticina races in the seedling test and final disease severity (FDS) in adult plant stage on wheat cultivars/germplasms with slow-rusting resistance in field trials in Baoding, Hebei during 2016 to 2018

\begin{tabular}{|c|c|c|c|c|c|}
\hline Line no. ${ }^{\mathbf{a}}$ & Cultivar & Genes $^{\mathbf{b}}$ & ITs in seedlings ${ }^{c}$ & Mean FDS (\%) in 2017 & Mean FDS $(\%)$ in 2018 \\
\hline 3 & Zhongzuo 50009 & Lr34 & 3 & 25 & 35 \\
\hline 4 & Yanda 1817 & $\operatorname{Lr} 34$ & 3 & 10 & 20 \\
\hline 7 & Dexuan 1 & & 3 & 45 & 35 \\
\hline 10 & Beijing 8 & Lr46 & 4 & 5 & 10 \\
\hline 13 & 54405 & $\operatorname{Lr} 34,+^{\mathrm{d}}$ & 3 & 5 & 15 \\
\hline 15 & Pulin 5 & Lr34 & 3 & 25 & 45 \\
\hline 16 & Luzhan 1 & $\operatorname{Lrl}, \operatorname{Lr} 46,+$ & 3 & 10 & 15 \\
\hline 18 & Changwei 18 & $\operatorname{Lr} 34, \operatorname{Lr} 46,+$ & 3 & 15 & 5 \\
\hline 19 & Jingzuo 278 & Lr46 & 3 & 5 & 10 \\
\hline 23 & Kechun 14 & Lr34 & 3 & 10 & 30 \\
\hline 24 & Linfen 10 & $\operatorname{Lrl}, \operatorname{Lr} 46,+$ & 3 & 10 & 5 \\
\hline 28 & Fengkang 15 & Lr34 & 4 & 35 & 20 \\
\hline 31 & Kedong 83 & $\operatorname{Lr} 46,+$ & 3 & 10 & 5 \\
\hline 34 & Jing 411 & Lr46 & 4 & 5 & 5 \\
\hline 35 & Anhui 3 & $L r 46$ & 4 & 10 & 10 \\
\hline 37 & Jinghong 4 & $\operatorname{Lr} 34,+$ & 3 & 10 & 35 \\
\hline 38 & Mianyang 62-31 & Lr46 & 3 & 10 & 5 \\
\hline 40 & Shuwan 8 & $\operatorname{Lr} 34, \operatorname{Lr} 46,+$ & 3 & 1 & 5 \\
\hline 41 & Wangmai 17 & $\mathrm{Lr} 46$ & 4 & 10 & 10 \\
\hline 42 & Weidong 4 & Lr34, + & 4 & 5 & 5 \\
\hline 44 & Xuyue 6 & & & 15 & 40 \\
\hline 45 & Jinmai 20 & Lr34 & 4 & 10 & 15 \\
\hline 49 & Linmai 6 & $\operatorname{Lr} 46,+$ & 4 & 5 & 10 \\
\hline 50 & Ningmai 1 & & 3 & 40 & 30 \\
\hline 59 & E'mai 9 & Lr34 & 3 & 5 & 30 \\
\hline 61 & Xinyang 1 & & 4 & 55 & 35 \\
\hline 67 & Yangmai 17 & & 3 & 55 & 30 \\
\hline 71 & Xiaoyan 4 & & 4 & 20 & 60 \\
\hline 93 & Pingliang 32 & Lr34 & 4 & 5 & 5 \\
\hline 110 & PI 660092 & Lr34 & 3 & 5 & 20 \\
\hline 111 & PI 660099 & Lr46 & 4 & 5 & 5 \\
\hline 113 & PI 660110 & $L r 46$ & 4 & 1 & 10 \\
\hline 114 & PI 660111 & $L r 1, L r 46$ & 3 & 15 & 10 \\
\hline \multirow[t]{3}{*}{115} & PI 660113 & Lr33, Lr46 & 4 & 10 & 5 \\
\hline & Zhengzhou 5389e & & 4 & 80 & 100 \\
\hline & Saare & & 4 & 1 & 3 \\
\hline
\end{tabular}

\footnotetext{
${ }^{a}$ Line numbers correspond to those in Table 1.

$\mathrm{b}$ Adult-plant resistance genes based on molecular marker.

c According to the 0 to 4 Stakman scale. $3=$ moderate size uredinia, 4 = large uredinia.

$\mathrm{d}+$ indicates unidentified all-stage gene postulated by seedling test in the greenhouse as in Table 4.

e Susceptible check: Zhengzhou 5389 and resistant check: Saar for adult-plant resistance.
} 
(Lillemo et al. 2008), giving it more value in wheat breeding. Except Pavon 76, Lr46 resistance has been reported in CIMMYT cultivars Pavon, Attila, Francolin\#1, Saar, Pastor, Oligo, Kundan, Sujata, Kenya Kongoni, and Quaiu 3 (Basnet et al. 2013; Calvo-Salazar et al. 2015; Lan et al. 2015; Li et al. 2014; Lillemo et al. 2008; Ponce-Molina et al. 2018; Rosewarne et al. 2012), Uruguay landrace Amercano 25e (Kolmer et al. 2013), and Indian wheat Sujata (Lan et al. 2014) and Kundan (Ren et al. 2017). In this study, 16 wheat accessions were identified having $L r 46$ and showing good resistance in the adult-plant stage in fields. None of the above Lr46 carrying cultivars are present in the pedigrees of the accessions postulated as having Lr46 in this study. Lr46 probably has more distribution in the wheat gene pool, and the $L r 46$ in our collections has other origins.

Generally, the combination of adult-plant resistance with one or more other genes can confer higher level resistance than any APR genes using singly (German and Kolmer 1992; Kolmer 1992). Lr34 and/or Lr46 together with other resistance genes significantly enhanced the resistance level to leaf rust in the reported cultivars (Kolmer et al. 2013; Lan et al. 2014; Singh et al. 1998). Similarly, we found the combination of $2 r 46$ with other genes in six cultivars conferred high level resistance to leaf rust in two-year field trials with mean FDS from 3 to $12.5 \%$, and Lr34 with Lr46 together reached a mean FDS of 3 to $10 \%$. Even if $L r 26, L r 1$, or $L r 13$ is not effective to some $P$. triticina races in China, the combination of these genes with $L r 34$ or $L r 46$ achieved better resistance in the fields as observed in this study. Cultivars Kedong 83, Weidong 4, Jinghong 4, Linmai 6, and 54405 carrying both APR and seedling resistance displayed very high-level resistance in fields. The combination of APR and seedling resistance can enhance the durability of leaf rust resistance in wheat cultivars; this approach can be considered in wheat breeding. Except for Lr34 and Lr46, two other slow rusting resistance genes, $\operatorname{Lr} 67$ and $L r 68$, are an important resource for leaf rust resistance (Herrera-Foessel et al. 2011, 2012). Since the seeds and DNA of $\operatorname{Lr} 67$ and $\operatorname{Lr} 68$ were not available in this study, whether these two genes exist in our collection will assessed in the future.

In this study, we identified 34 wheat lines with slow rusting resistance for leaf rust; these wheat lines can be used as a resistance resource in Chinese wheat breeding, especially some germplasms from a diverse global landrace collection including PI 660068, PI 660069, PI 660072, PI 660073, PI 660078, PI 660087, PI 660092, PI 660099, PI 660110, PI 660111, PI 660113, and PI 660123. They also showed good stripe rust resistance in the U.S.A. (Wang et al. 2012) and China (Zhou et al. 2015), and displayed good agronomic traits, such as excellent tillering, plump spikes, lodge resistance, and early maturity (Wang et al. 2012), which can be used to develop multiple rust resistance, enrich resistance genetic background, and improve agronomic traits in wheat cultivars.

Our findings showed the usefulness of using molecular marker technology and gene postulation in identifying wheat leaf rust resistance genes. However, outside of 44 wheat lines identified with $\mathrm{Lr}$ genes, 40 wheat lines might contain unknown gene(s). Therefore, genetic analysis methods should be further used for gene identification. The next step is for genetic biparental populations to be constructed by crossing these resistant lines with other susceptible lines for gene identification. As the development of sequencing technology and high throughput molecular markers continues, this technology can be well used in gene mapping for rust resistance. This research finding could be beneficial to wheat resistance breeding.

\section{Acknowledgments}

We thank Dr. M. N. Wang, Department of Plant Pathology, Washington State University, for a critical review of this manuscript.

\section{Literature Cited}

Adhikari, L., and Missaoui, A. M. 2019. Quantitative trait loci mapping of leaf rust resistance in tetraploid alfalfa. Physiol. Mol. Plant Pathol. 106: 238-245.

Ausemus, E. R., Harrington, J. B., Reitz, L. P., and Worzella, W. W. 1946. A summary of genetic studies in hexaploid and tetraploid wheats. J. Am. Soc. Agron. 38:1082-1099.
Bansal, U. K., Hayden, M. J., Venkata, B. P., Khanna, R., Saini, R. G., and Briana, H. S. 2008. Genetic mapping of adult plant leaf rust resistance genes $L r 48$ and Lr49 in common wheat. Theor. Appl. Genet. 117:307-312.

Basnet, B. R., Singh, R. P., Herrera-Foessel, S. A., Ibrahim, A. M. H., HuertaEspino, J., Calvo-Salazar, V., and Rudd, J. C. 2013. Genetic analysis of adult plant resistance to yellow rust and leaf rust in common spring wheat Quaiu 3. Plant Dis. 97:728-736.

Calvo-Salazar, V., Singh, R. P., Huerta-Espino, J., Cruz-Izquierdo, S., LobatoOrtiz, R., Sandoval-Islas, S., Vargas-Hernández, M., German, S., Silva, P. Basnet, B. R., Lan, C. X., and Herrera-Foessel, S. A. 2015. Genetic analysis of resistance to leaf rust and yellow rust in spring wheat cultivar Kenya Kongoni. Plant Dis. 99:1153-1160.

Chai, J. F., Zhou, R. H., Jia, J. Z., and Liu, X. 2006. Development and application of a new co-dominant PCR marker for detecting $1 \mathrm{BL} \cdot 1 \mathrm{RS}$ wheat-rye chromosome translocations. Plant Breed. 125:302-304.

Chen, W. Q., and Wang, J. X. 1997. Genes for leaf and stem rust resistance in 76 wheat genetic resources. Acta Agron. Sin. 23:655-663.

de Froidmont, D. 1998. A co-dominant marker for the 1BL/1RS wheat-rye translocation via multiplex PCR. J. Cereal Sci. 27:229-232.

Dubin, H. J., Johnson, R., and Stubbs, R. W. 1989. Postulated genes for resistance to stripe rust in selected CIMMYT and related wheats. Plant Dis. 73:472-475.

Dubin, H. J., and Torres, E. 1981. Causes and consequences of the 1976-1977 wheat leaf rust epidemic in North west Mexico. Annu. Rev. Phytopathol. 19: 41-49.

Dyck, P. L. 1977. Genetics of leaf rust reaction in three introductions of common wheat. Can. J. Genet. Cytol. 19:711-716.

Dyck, P. L. 1987. The association of a gene for leaf rust resistance with the chromosome 7D suppressor of stem rust resistance in common wheat. Genome 29:467-469.

Dyck, P. L. 1991. Genetics of adult-plant leaf rust resistance in 'Chinese Spring' and 'Sturdy' wheats. Crop Sci. 31:309-311.

Dyck, P. L., Kerber, E. R., and Lukow, O. M. 1987. Chromosome location and linkage of a new gene (Lr33) for reaction to Puccinia recondite in common wheat. Genome 29:463-466.

Flor, H. H. 1956. The complementary genic systems in flax and flax rust. Adv Genet. 8:29-54

Gao, P., Zhou, Y., Gebrewahid, T. W., Zhang, P. P., Yan, X. C., Li, X., Yao, Z. H. Li, Z. F., and Liu, D. Q. 2019. Identification of known leaf rust resistance genes in common wheat cultivars from Sichuan province in China. Crop Prot. 115 122-129.

Gebrewahid, T. W., Yao, Z. J., Yan, X. C., Gao, P., and Li, Z. F. 2017 Identification of leaf rust resistance genes in Chinese common wheat cultivars. Plant Dis. 101:1729-1737.

German, S. E., and Kolmer, J. A. 1992. Effect of gene Lr34 in the enhancement of resistance to leaf rust of wheat. Theor. Appl. Genet. 84:97-105.

Gupta, S. K., Charpe, A., Prabhu, K. V., and Haque, Q. M. R. 2006. Identification and validation of molecular markers linked to the leaf rust resistance gene $\operatorname{Lr} 19$ in wheat. Theor. Appl. Genet. 113:1027-1036.

Hartman, G. L., Miles, M. R., and Frederick, R. D. 2005. Breeding for resistance to soybean rust. Plant Dis. 89:664-666.

He, Z. H., Rajaram, S., Xin, Z. Y., and Zhang, G. Z. 2001. A history of wheat breeding in China. CIMMYT, D. F., Mexico.

Helguera, M., Khan, I. A., Kolmer, J., Lijavetzky, D., Zhongqi, L., and Dubcovsky, J. 2003. PCR assays for the Lr37-Yr17-Sr38 cluster of rust resistance genes and their use to develop isogenic hard red spring wheat lines. Crop Sci. 43:1839-1847.

Herrera-Foessel, S. A., Lagudah, E. S., Huerta-Espino, J., Hayden, M. J., Bariana H. S., Singh, D., and Singh, R. P. 2011. New slow-rusting leaf rust and stripe rust resistance genes $\operatorname{Lr67}$ and $\mathrm{Yr} 46$ in wheat are pleiotropic or closely linked. Theor. Appl. Genet. 122:239-249.

Herrera-Foessel, S. A., Singh, R. P., Huerta-Espino, J., Rosewarne, G. M. Periyannan, S. K., Viccars, L., Calvo-Salazar, V., Lan, C. X., and Lagudah, E. S. 2012. Lr68: a new gene conferring slow rusting resistance to leaf rust in wheat. Theor. Appl. Genet. 124:1475-1486.

Hiebert, C. W., Thomas, J. B., Somers, D. J., McCallum, B. D., and Fox, S. L. 2007. Microsatellite mapping of adult-plant leaf rust resistance gene $L r 22 a$ in wheat. Theor. Appl. Genet. 115:877-884.

Khan, M. H., Bukhari, A., Dar, Z. A., and Rizvi, S. M. 2013. Status and strategies in breeding for rust resistance in wheat. Agric. Sci. 04:292-301.

Kolmer, J. A. 1992. Enhanced leaf rust resistance in wheat conditioned by resistance gene pairs with $\operatorname{Lrl3}$. Euphytica 61:123-130.

Kolmer, J. A. 2003. Postulation of leaf rust resistance genes in selected soft red winter wheats. Crop Sci. 43:1266-1274

Kolmer, J. A., Mert, Z., Akan, K., Demir, L., Ünsal, R., Sermet, C., Keser, M., Akin, B., and Morgounov, A. 2013. Virulence of Puccinia triticina in Turkey and leaf rust resistance in Turkish wheat cultivars. Eur. J. Plant Pathol. 135:703-716.

Kolmer, J. A., Singh, R. P., Garvin, D. F., Viccars, L., William, H. M., HuertaEspino, J., Ogbonnaya, F. C., Raman, H., Orford, S., Bariana, H. S., and Lagudah, E. S. 2008. Analysis of the $L r 34 / Y r 18$ rust resistance region in wheat germplasm. Crop Sci. 48:1841-1852.

Lagudah, E. S., Krattinger, S. G., Herrera-Foessel, S., Singh, R. P., Huerta-Espino, J., Spielmeyer, W., Brown-Guedira, G., Selter, L. L., and Keller, B. 2009. Gene- 
specific markers for the wheat gene $\mathrm{Lr} 34 / \mathrm{Yr} 18 / \mathrm{Pm} 38$ which confers resistance to multiple fungal pathogens. Theor. Appl. Genet. 119:889-898.

Lagudah, E. S., McFadden, H., Singh, R. P., Huerta-Espino, J., Bariana, H. S., and Spielmeyer, W. 2006. Molecular genetic characterization of the Lr34/Yr18 slow rusting resistance gene region in wheat. Theor. Appl. Genet. 114:21-30.

Lan, C. X., Rosewarne, G. M., Singh, R. P., Herrera-Foessel, S. A., Huerta-Espino, J., Basnet, B. R., Zhang, Y. L., and Yang, E. N. 2014. QTL characterization of resistance to leaf rust and stripe rust in the spring wheat line Francolin\#1. Mol. Breed. 34:789-803.

Lan, C. X., Zhang, Y. L., Herrera-Foessel, S. A., Basnet, B. R., Huerta-Espino, J., Lagudah, E. S., and Singh, R. P. 2015. Identification and characterization of pleiotropic and co-located resistance loci to leaf rust and stripe rust in bread wheat cultivar Sujata. Theor. Appl. Genet. 128:549-561.

Li, X. J, Xu, X., Liu, W. H., Li, X. Q., and Li, L. H. 2009. Genetic diversity of the founder parent Orofen and its progenies revealed by SSR markers. Sci. Agric. Sin. 42:3397-3404.

Li, Z. F., Lan, C. X., He, Z. H., Singh, R. P., Rosewarne, G. M., Chen, X. M., and Xia, X. C. 2014. Overview and application of QTL for adult plant resistance to leaf rust and powdery mildew in wheat. Crop Sci. 54:1907-1925.

Li, Z. F., Xia, X. C., He, Z. H., Li, X., Zhang, L. J., Wang, H. Y., Meng, Q. F., Yang, W. X., Li, G. Q., and Liu, D. Q. 2010. Seedling and slow rusting resistance to leaf rust in Chinese wheat cultivars. Plant Dis. 94:45-53.

Lillemo, M., Asalf, B., Singh, R. P., Huerta-Espino, J., Chen, X. M., He, Z. H., and Bjørnstad, A. 2008. The adult plant rust resistance loci $\mathrm{Lr34/Yr18}$ and $\mathrm{Lr} 46 /$ Yr29 are important determinants of partial resistance to powdery mildew in bread wheat line Saar. Theor. Appl. Genet. 116:1155-1166.

Loegering, W. Q., McIntosh, R. A., and Burton, C. H. 1971. Computer analysis of disease data to derive hypothetical genotypes for reaction of host varieties to pathogens. Can. J. Genet. Cytol. 13:742-748.

Long, D. L., and Kolmer, J. A. 1989. A North American system of nomenclature for Puccinia recondita f. sp. tritici. Phytopatholoyg 79:525-529.

Mains, E. B., Leighty, C. E., and Johnston, C. O. 1926. Inheritance of resistance to leaf rust Puccinia triticina Erikss., in crosses of common wheat, Triticum vulgare Vill. J. Agric. Res. 32:931-972.

McIntosh, R. A. 1976. Genetics of wheat and wheat rusts since Farrer. Farrer Memorial Oration 1976. J. Aust. Inst. Agric. Sci. 42:203-216.

McIntosh, R. A., Dubcovsky, J., Rogers, W. J., Morris, C., and Xia, X. C. 2017. Catalogue of gene symbols for wheat: 2017 supplement. Available at: https:// shigen.nig.ac.jp/wheat/komugi/genes/macgene/supplement2017.pdf

McIntosh, R. A., Friebe, B., Jiang, J., The, D., and Gill, B. S. 1995. Cytogenetical studies in wheat XVI. Chromosome location of a new gene for resistance to leaf rust in a Japanese wheat-rye translocation line. Euphytica 82:141-147.

Neu, C., Stein, N., and Keller, B. 2002. Genetic mapping of the Lr20-PmI resistance locus reveals suppressed recombination on chromosome arm 7AL in hexaploid wheat. Genome 45:737-744.

Ponce-Molina, L. J., Huerta-Espino, J., Singh, R. P., Basnet, B. R., Alvarado, G., Randhawa, M. S., Lan, C. X., Aguilar-Rincon, V. H., Lobato-Qrtiz, R., and Garcia-Zavala, J. J. 2018. Characterization of leaf rust and stripe rust resistance in spring wheat 'Chilero'. Plant Dis. 102:421-427.

Qiu, J. W., Schürch, A. C., Yahiaoui, N., Dong, L. L., Fan, H. J., Zhang, Z. J., Keller, B., and Ling, H. Q. 2007. Physical mapping and identification of a candidate for the leaf rust resistance gene $L r l$ of wheat. Theor. Appl. Genet. 115:159-168.

Randhawa, M., Bansal, U., Lillemo, M., Miah, H., and Bariana, H. 2016. Postulation of rust resistance genes in Nordic spring wheat genotypes and identification of widely effective sources of resistance against the Australian rust flora. J. Appl. Genet. 57:453-465.

Ren, Y., Singh, R. P., Basnet, B. R., Lan, C. X., Huerta-Espino, J., Lagudah, E. S., and Ponce-Molina, L. J. 2017. Identification and mapping of adult plant resistance loci to leaf rust and stripe rust in common wheat cultivar Kundan. Plant Dis. 101:456-463.

Roelfs, A. P., Singh, R. P., and Saari, E. E. 1992. Rust diseases of wheat: Concepts and methods of disease management. CIMMYT, DF, Mexico.

Rosewarne, G. M., Singh, R. P., Huerta-Espino, J., Herrera-Foessel, S. A., Forrest, K. L., Hayden, M. J., and Rebetzke, G. J. 2012. Analysis of leaf and stripe rust severities reveals pathotype changes and multiple minor QTLs associated with resistance in an Avocet $\times$ Pastor wheat population. Theor. Appl. Genet. 124: 1283-1294.

Schachermayr, G., Feuillet, C., and Keller, B. 1997. Molecular markers for the detection of the wheat leaf rust resistance gene $\mathrm{LrlO}$ in diverse genetic background. Mol. Breed. 3:65-74.

Schachermayr, G., Siedler, H., Gale, M. D., Winzeler, H., Winzeler, M., and Keller, B. 1994. Identification and localization of molecular markers linked to the $L r 9$ leaf rust resistance gene of wheat. Theor. Appl. Genet. 88:110-115.

Schachermayr, G. M., Messmer, M. M., Feuillet, C., Winzeler, H., Winzeler, M., and Keller, B. 1995. Identification of molecular markers linked to the
Agropyron elongatum-derived leaf rust resistance gene $L r 24$ in wheat. Theor. Appl. Genet. 90:982-990.

Seah, S., Bariana, H., Jahier, J., Sivasithamparam, K., and Lagudah, E. S. 2001 The introgressed segment carrying rust resistance genes $\mathrm{Yr} 17, \mathrm{Lr} 37$ and $\mathrm{Sr} 38$ in wheat can be assayed by a cloned disease resistance gene-like sequence. Theor. Appl. Genet. 102:600-605.

Sharp, P. J., Kreis, M., Shewry, P. R., and Gale, M. D. 1988. Location of $\beta$-amylase sequence in wheat and its relatives. Theor. Appl. Genet. 75:286-290

Singh, D., Park, R. F., and McIntosh, R. A. 2007. Characterization of wheat leaf rust resistance gene $\mathrm{Lr} 34$ in Australian wheats using components of resistance and the linked molecular marker csLV34. Aust. J. Agric. Res. 58: $1106-1114$.

Singh, R. P. 1992. Association between gene Lr34 for leaf rust resistance and leaf tip necrosis in wheat. Crop Sci. 32:874-878.

Singh, R. P., Chen, W. Q., and He, Z. H. 1999. Leaf rust resistance of spring, facultative, and winter wheat cultivars from China. Plant Dis. 83:644-651.

Singh, R. P., Herrera-Foessel, S. A., Huerta-Espino, J., Lan, C. X., Basnet, B. R. Bhavani, S., and Lagudah, E. S. 2013. Pleiotropic gene Lr46/Yr29/Pm39/Ltn2 confers slow rusting, adult plant resistance to wheat stem rust fungus. Page 17.1 in: Proceedings Borlaug Global Rust Initiative, 2013 Technical Workshop, 1922 August, New Dehli, India.

Singh, R. P., Huerta-Espino, J., and Rajaram, S. 2000. Achieving near-immunity to leaf and stripe rust in wheat by combining slow rusting resistance genes. Acta Phytopathol. Entomol. Hung. 35:133-139.

Singh, R. P., Mujeeb-Kazi, A., and Huerta-Espino, J. 1998. Lr46: a gene conferring slow-rusting resistance to leaf rust in wheat. Phytopathology 88:890-894.

Sokal, R. R., and Rohlf, F. J. 1989. Introduction to Biostatistics, 2nd Ed. W. H. Freeman and Co., New York.

Villareal, R. L., Rajaram, S. A., Mujeeb-Kazi, A., and Del Toro, E. 2006. The effect of chromosome $1 \mathrm{~B} / 1 \mathrm{R}$ translocation on the yield potential of certain spring wheats (Triticum aestivum L.). Plant Breed. 10:77-81.

Wang, J. Z., Shi, L. Z., Zhu, L., Li, X., and Liu, D. Q. 2014. Genetic analysis and molecular mapping of leaf rust resistance genes in the wheat line 5R618. Czech J. Plant Breed. 50:262-267.

Wang, M. N., Chen, X. M., Xu, L. S., Cheng, P., and Bockelman, H. E. 2012. Registration of 70 common spring wheat germplasm lines resistant to stripe rust. J. Plant Regist. 6:104-110.

William, H. M., Singh, R. P., Huerta-Espino, J., Palacios, G., and Suenaga, K. 2006. Characterization of genetic loci conferring adult plant resistance to leaf rust and stripe rust in spring wheat. Genome 49:977-990.

William, M., Singh, R. P., Huerta-Espino, J., Ortiz Islas, S., and Hoisington, D. 2003. Molecular marker mapping of leaf rust resistance gene Lr46 and its association with stripe rust resistance gene $Y r 29$ in wheat. Phytopathology 93:153-159.

Yan, X. C., Li, Z. F., Yang, H. L., Zhang, H. H., Gebrewahid, T. W., Yao, Z. J., Liu, D. Q., and Zhou, Y. 2017. Analysis of wheat leaf rust resistance genes in 30 important wheat cultivars. Sci. Agric. Sin. 50:272-285.

Yang, W. X., Yang, F. P., Liang, D., He, Z. H., Shang, X. W., and Xia, X. C. 2008 Molecular characterization of slow-rusting genes $\mathrm{Lr} 34 / \mathrm{Yr} 18$ in Chinese wheat cultivars. Acta Agron. Sin. 34:1109-1113.

Yu, X. H., Kong, H. Y., Meiyalaghan, V., Casonato, S., Chng, S. F., Jones, E. E., Butler, R. C., Pickering, R., and Johnston, P. A. 2018. Genetic mapping of a barley leaf rust resistance gene Rph26 introgressed from Hordeum bulbosum. Theor. Appl. Genet. 131:2567-2580.

Yuan, J. H., Liu, T. G., and Chen, W. Q. 2007. Postulation of leaf rust resistance genes in 47 new wheat cultivars (lines) at seedling stage. Sci. Agric. Sin. 40:1925-1935.

Zhang, P. P., Gebrewahid, T. W., Zhou, Y., Li, Q. L., Li, Z. F., and Liu, D. Q. 2019 Seedling and adult plant resistance to leaf rust in 46 Chinese bread wheat landraces and 39 wheat lines with known $L r$ genes. J. Integr. Agric. 18:1014-1023.

Zhang, P. P., Qi, A. Y., Zhou, Y., Xia, X. C., He, Z. H., Li, Z. F., and Liu, D. Q. 2017. Quantitative trait loci mapping of adult-plant resistance to leaf rust in a Fundulea $900 \times$ 'Thatcher' wheat cross. Plant Breed. 136:1-7.

Zhou, H. X., Xia, X. C., He, Z. H., Li, X., Wang, C. F., Li, Z. F., and Liu, D. Q. 2013. Molecular mapping of leaf rust resistance gene LrNJ97 in Chinese wheat line Neijiang 977671. Theor. Appl. Genet. 126:2141-2147.

Zhou, X. L., Zhan, G. M., Huang, L. L., Han, D. J., and Kang, Z. S. 2015 Evaluation of resistance to stripe rust in eighty abroad spring wheat germplasms. Sci. Agric. Sin. 48:1518-1526.

Zhou, Y., He, Z. H., Zhang, G. S., Xia, L. Q., Chen, X. M., Gao, Y. C., Jing, Z. B., and $\mathrm{Yu}, \mathrm{G}$. J. 2004. Utilization of 1BL/1RS translocation in wheat breeding in China. Acta Agron. Sin. 30:531-535.

Zhou, Y., Zhu, H. Z., Cai, S. B., He, Z. H., Zhang, X. K., Xia, X. C., and Zhang, G. S. 2007. Genetic improvement of grain yield and associated traits in the southern China winter wheat region: 1949 to 2000. Euphytica 157:465-473.

Zhuang, Q. S. 2003. Chinese wheat improvement and pedigree analysis. China Agriculture Press, Beijing. 